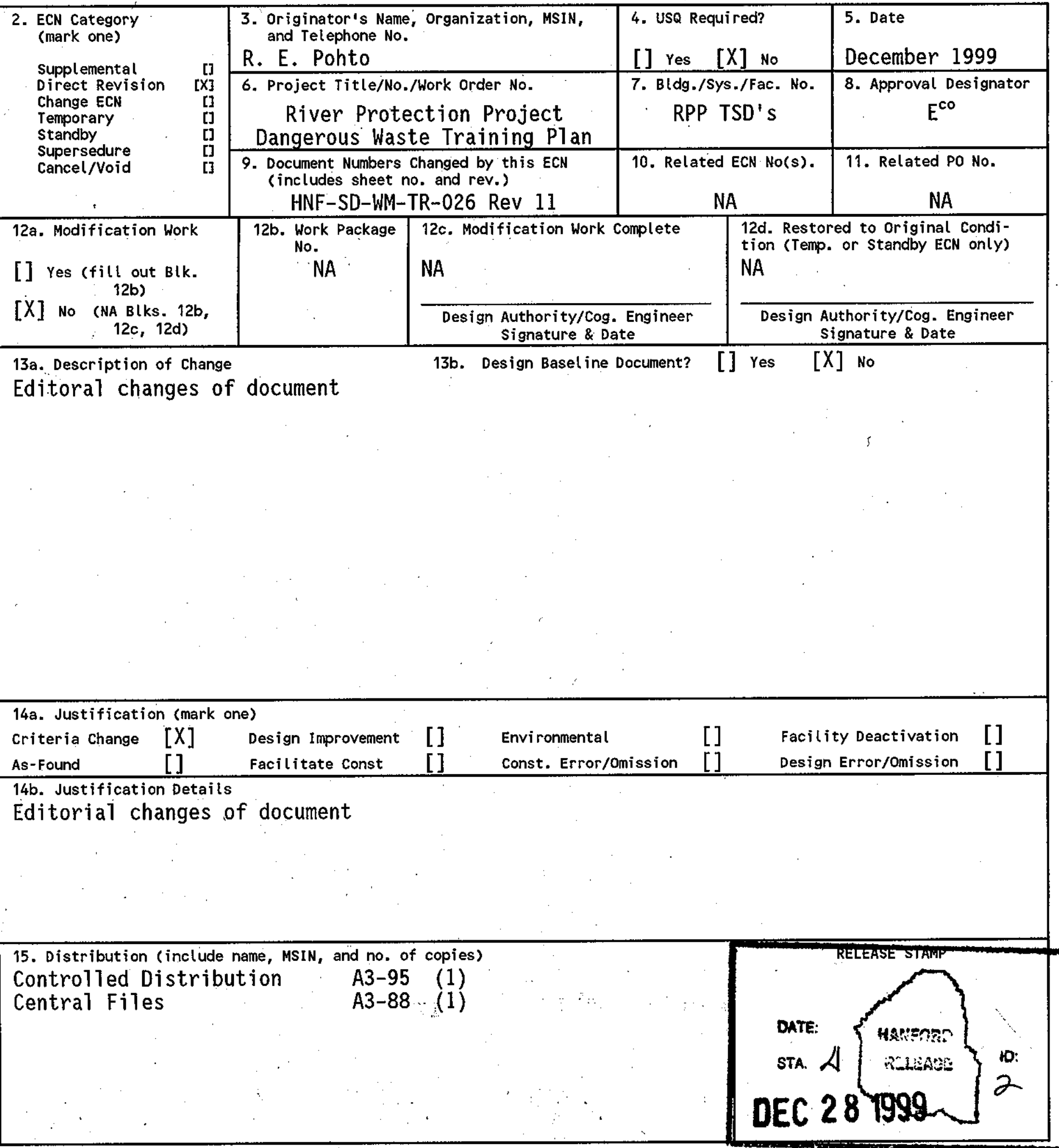




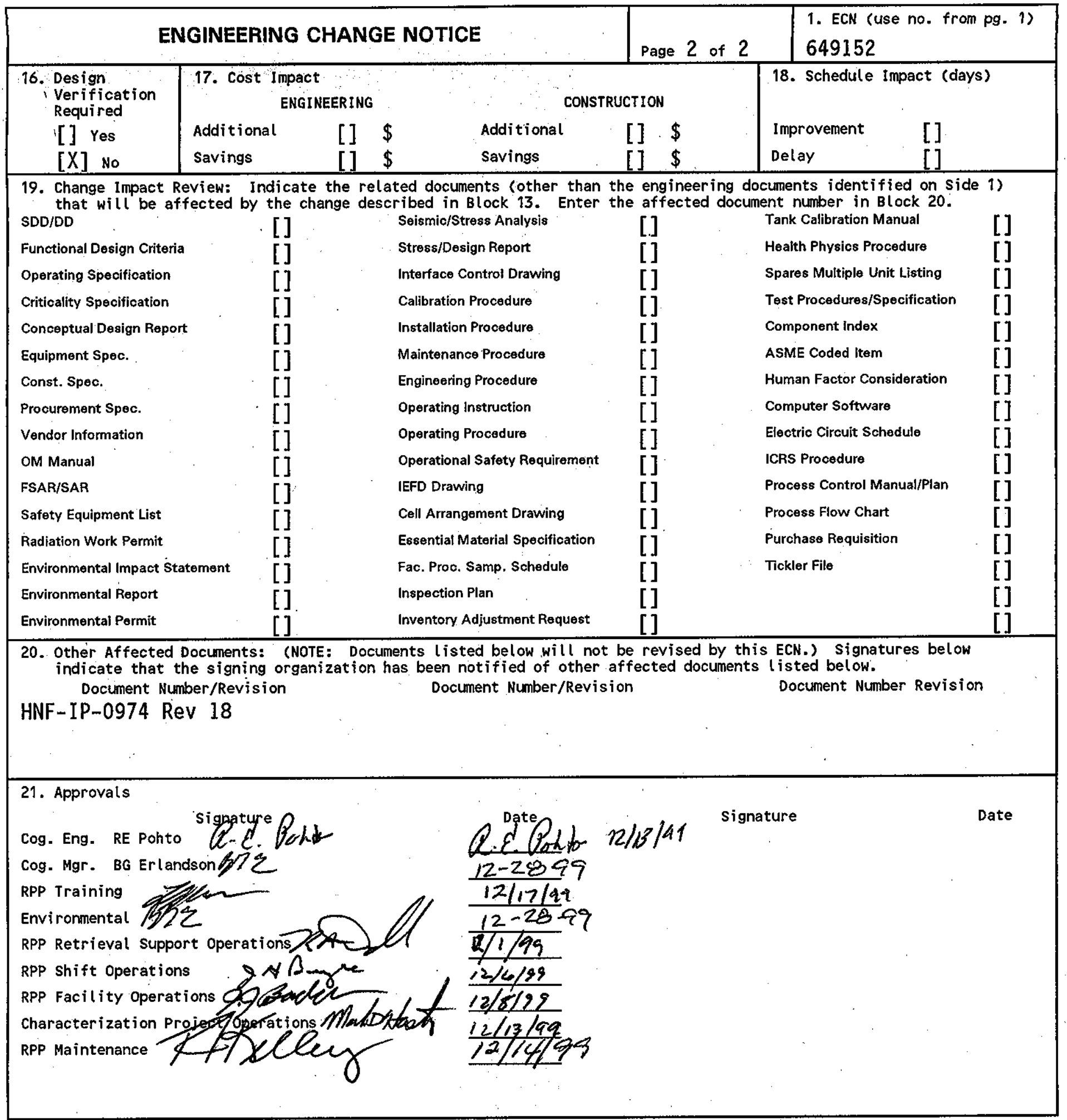




\section{River Protection Project Dangerous Waste Training Plan}

RE Pohto

Lockheed Martin Hanford Corporation, Richland, WA 99352

U.S. Department of Energy Contract DE-AC06-99RL14047

EDT/ECN: 649152

Org Code: 79600

B\&R Code: EW3120071

UC: 2030

Charge Code: 101785

Total Pages: 5861

2212.2899.

Key Words: Dangerous Waste, RCRA, WAC 173-303

Abstract: This supporting document contains the training plan for dangerous waste management at River Protection Project TSD Units

TRADEMARK DISCLAIMER. Reference herein to any specific commercial product, process, or service by trade name, trademark, manufacturer, or otherwise, does not necessarily constitute or imply its endorsement, recommendation, or favoring by the United States Government or any agency thereof or its contractors or subcontractors.

Printed in the United States of America. To obtain copies of this document, contact: Document Control Services, P.O. Box 950, Mailstop H6-08, Richland WA 99352, Phone (509) 372-2420; Fax (509) $376-4989$.
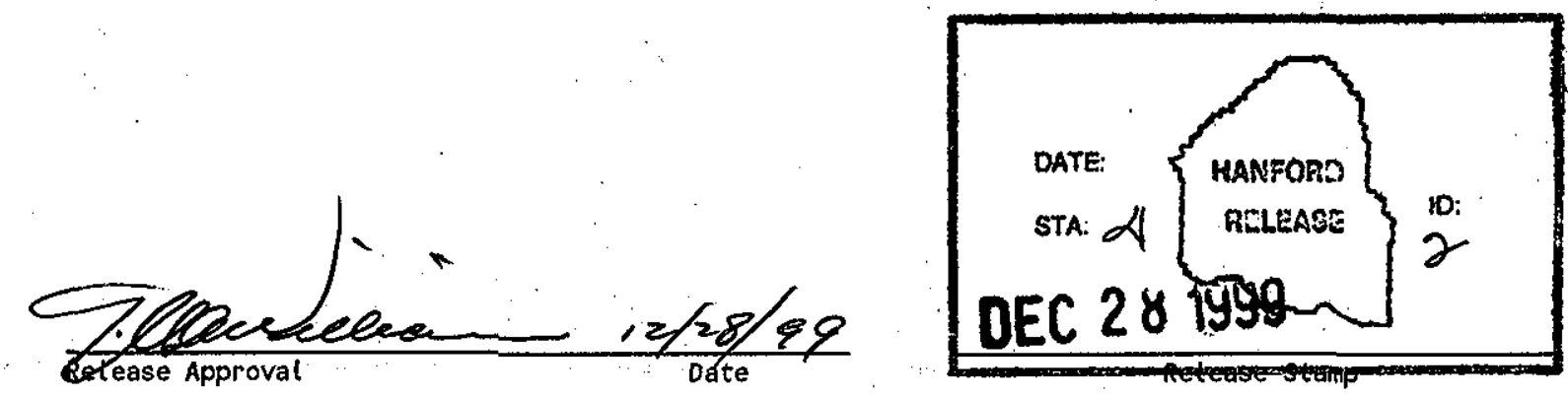

Approved for Public Release 
(2) Title

River Protection Project Dangerous Waste Training Plan

CHANGE CONTROL RECORD

\begin{tabular}{|c|c|c|c|c|}
\hline \multirow{2}{*}{ (3) } & \multirow{2}{*}{ Revision } & \multirow{2}{*}{ (4) Description of Change - Replace, Add, and Delete Pages } & \multicolumn{2}{|c|}{ Authorized for Release } \\
\hline & & & (5) Cog. Engr. & (6) Cog. Mgr. \\
\hline & 12 & Replace all pages Per ECN-649152 12/31/99 & RE Pohto & $\mathrm{BG}$ Erland $\$ 95 \%$ \\
\hline & no & 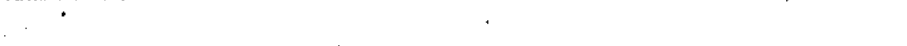 & Sho & \\
\hline & & . & $12-28 \pi$ & \\
\hline & & & & \\
\hline & & & & \\
\hline & & & & \\
\hline & & & & \\
\hline & & & & \\
\hline & & & & \\
\hline & & & & \\
\hline & & & & \\
\hline & re & & & \\
\hline & & & & \\
\hline & & & & \\
\hline & & & & \\
\hline & & & & \\
\hline & & & & \\
\hline & & & & \\
\hline & & & & \\
\hline & & & & \\
\hline & & & . & \\
\hline & & · & & \\
\hline & & & & \\
\hline & & & & \\
\hline & & . & & \\
\hline & & & & \\
\hline & & $r$ & & \\
\hline
\end{tabular}


RECORD OF REVISION

(1) Document Number

HNF-SD-WM-TR-026

Page 1

(2) Title

River Protection Project Dangerous Waste Training Plan

CHANGE CONTROL RECORD

\begin{tabular}{|c|c|c|c|}
\hline \multirow{2}{*}{ Revision } & \multirow{2}{*}{ (4) Description of Change - Replace, Add, and Delete Pages } & \multicolumn{2}{|c|}{ Authorized for Release } \\
\hline & & (5) Cog. Engr. & (6) Cog. Mgr. \\
\hline 0 & (7) $\quad$ EDT-603526 $12 / 22 / 93$ & KJ Anderson & RB Barmettlor \\
\hline 1 & Replace al1 pages Per ECN-611409 6/30/94 & KJ Anderson & T Morton \\
\hline 2 & Replace al1 pages Per ECN-616371 10/31/94 & KJ Anderson & T Morton \\
\hline 3 & Replace al1 pages Per ECN-623989 7/20/95 & KJ Anderson & T Morton \\
\hline $3 A$ & $\begin{array}{l}\text { Replace Pages } 18,27,28,29, B-1, B-2, B-4 \\
\text { and B-5, Remove Pages A-13-A-26 and } \\
\text { Replace with Pages A-13-A-34 Per } \\
\text { ECN-611410 8/31/95 }\end{array}$ & KJ Anderson & LE Simmons \\
\hline 4 & Replace al1 Pages Per ECN-629561 2/21/96 & KJ Anderson & L.E Simmons \\
\hline $4 \mathrm{~A}$ & $\begin{array}{l}\text { Replace Pages } i-i v, 1-3,9,14,22,25-30 \text {, } \\
A-i, A-4, B-i, B-1, B-3, B-4, B-5, \text { and } B-7 \\
\text { Insert Pages } 14 A, 14 B, A-33 \text {, and } A-34 \text { Per } \\
\text { ECN-631260 5/30/96 }\end{array}$ & KJ Anderson & Fo Strankman \\
\hline $4 \mathrm{~B}$ & $\begin{array}{l}\text { Replace Pages } i-i v, 9,14 A, 14 B, 15,21 \text {, } \\
26-28,30, A-i, A-34, B-i, B-2 \text {, and } B-5 \\
\text { Insert Pages } A-35 \text { and } A-36 \text { Per ECN-631261 } \\
9 / 26 / 96\end{array}$ & KJ Anderson & TL Jennings \\
\hline . & . & & . \\
\hline 5 & Replace al1 Pages Per ECN-628822 6/01/97 & RE Pohto & BG Erlandson \\
\hline 6 & Replace all Pages Per ECN-644177 & RE, Pohto & BG Erlandson \\
\hline 7 & Replace al1 Pages Per ECN-610884 & RE Pohto & BG Erlandson \\
\hline 8 & Replace all Pages Per ECN-190924 12/31/98 & RE Pohto & BG Erlandson \\
\hline 9 & Replace al1 Pages Per ECN-610887 3/31/99 & RE Pohto & BG Erlandson \\
\hline 10 & Replace a11 Pages Per ECN-654113 & RE Pohto & BG. Erlandson \\
\hline & & & . \\
\hline 11 & Replace a11 Pages Per ECN-655266 & RE Pohto & BG Erlandson \\
\hline
\end{tabular}




\section{River Protection Project Dangerous Waste Training Plan}

R. E. Pohto

Lockheed Martin Hanford Corp.

Date Published

December 1999

Prepared for the U.S. Department of Energy Office of River Protection

LOCKUEED MATTIN

P. O. Box 1500

Richland, Washington

Contractor for the U.S. Department of Energy

Office of River Protection under Contract DE-AC06-99RL14047

Approved for Public Release; Further Dissemination Unlimited 
HNF-SD-WM-TR-026 Rev. 12

\section{RIVER PROTECTION PROJECT \\ DANGEROUS WASTE TRAINING PLAN}

December 1999

RPP Environmenta] 
TABLE OF CONTENTS

Acronyms

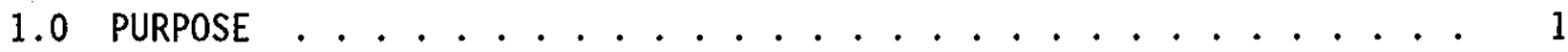

2.0 RESPONSIBILITIES . . . . . . . . . . . . . . . 1

2.1 RPP Responsibilities ............ 1

2.2 Training Organization Responsibilities........ 2

2.3 Environmental Organization Responsibilities ........ 2

2.4 Flour Daniel Northwest Responsibilities ......... 2

3.0 IMPLEMENTATION OF TRAINING PROGRAM . . . . . . . . . . . . . 2

3.1 Identification of Training . . . . . . . . . . . . . 3

3.2 Conduct of Training ............... . . 3

3.3 Evaluation of Training ............. 3

3.4 Documentation of Training ............. 3

4.0 DANGEROUS WASTE WORKER CATEGORIES . . . . . . . . . . 4

5.0 JOB POSITIONS AND DESCRIPTIONS . . . . . . . . . . 7

5.1 All Employees . . . . . . . . . . . . . . . 7

5.2 General Worker .............. 7

5.3 Advanced General Worker . . . . . . . . . . . . . 8

5.3.1 TMACS Operators ............... 10

5.3.2 Aging Waste Operators ............ 10

5.3.3 Mitigation Pump Operators ............ 10

5.3.4 204-AR Building Operators ............ 11

5.3.5 Drywe11 Operators ............... 11

5.3.6 Routines Operators .............. 11

5.3.7 Field Crew Operators ............. 12

5.3.8 Saltwell 0perators ............. 12

5.3.9 RPP Waste Retrieval .............. 12

5.3.10 Field Sampling Operators ........... 13

5.3.11 Core Sampling Operators ............. 13

5.3.11.1 Ground Crew Operator .......... 13

5.3.11.2 Push Mode Operator .......... . 13

5.3.11.3 Rotary Mode Operator .......... . 14

5.3.12 Cask/Sample Truck Operators: ........... 14

5.3.12A Characterization Project Routines

Operator ............ 14

5.3.13 Solid Waste Project Waste Operations-Truck .... 14

5.3.14 Solid Waste Project Waste Operations

Sampling/Repacking operators . . . . . . . 15

5.3.15 Solid Waste Project Waste Opentions Container

Document System Operators................. 15

5.3 .16 Solid Waste Project Waste-Operations

Surveillance/Inspection-operators_......... 15

5.4 General Manager ................. 16

5.4.1 RPP Environmental Compliance officer . . . . . 16

5.4.2 RPP Operations Shift Managers and Operations

5.4.3 Engineer ${ }_{\text {RPP Operations Support Managers . . . . . . . } 17} 17$

5.4.4 RPP Qualified Person-In-Charge (PIC) $\ldots 18$

5.4.5 Solid Waste Project Waste Operations-Managep... 18 
5.4.6 Solid-Waste Project Waste Operations Person-In

Eharge $(P I C)$
5.4 .7 RPP Hazardous Material Specialist . . . . . . . . . . . 19

5.5 General Shipper . . . . . . . . . . . . . . . 20

5.6 Waste Designator .. . . . . . . . . . . . . . . 20

6.0 TRAINING CONTENT, FREQUENCY, AND TECHNIQUES . . . . . . . . . . . 20

6.1 Relevance of Training to Job Positions . . . . . . . . . . 21

6.2 Training to Emergency Response . . . . . . . . . . . . . 22

6.3 Waste Management Orientation . . . . . . . . . . . 22

6.4 Waste Management Awareness . . . . . . . . . . . . . . . 22

6.5 Waste Management Advanced . . . . . . . . . . . . . . . 22

6.6 Waste Management Administration . . . . . . . . . . . . 23

6.7 Qualification Training ................. 23

6.8 Subcontractor Training and Visitor Training . . . . . . . 23

\section{List of Tables}

Table 1. Worker Categories................... . 5

Table 2. DOE-RL Program Area Descriptions . . . . . . . . . . . . . . . 6

Table 3. Certifications For Advanced General Workers (Nuclear

Chemical Operators) Associated With RPP TSD's . . . . . . 9

Table 4. RPP Facility Dangerous Waste Training Matrix ... . . . . . . . 24

Table 5. RPP Dangerous Waste Job-Specific Training Requirements For

Advanced General Workers (Nuclear Chemical Operators) . . . . . 25

Table 6. RPP. Dangerous Waste Job-Specific Training Requirements For

Managers And Engineers ............ 26

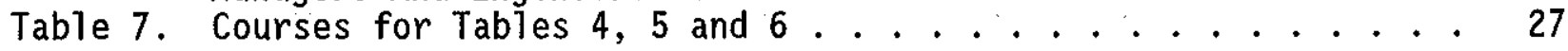

\section{List of Appendices}

Appendix A Training Course Descriptions . . . . . . . . . . . . A - i 


\section{Acronyms}

$\begin{array}{ll}\text { ACES } & \text { Access Control Entry System } \\ \text { BED } & \text { Building Emergency Director } \\ \text { CFR } & \text { Code of Federal Regulations } \\ \text { CPO } & \text { Characterization Project Operations } \\ \text { DOT } & \text { Department of Transportation } \\ \text { DST } & \text { Double-She11 Tank } \\ \text { ECO } & \text { Environmental Compl iance Officer } \\ \text { ECology } & \text { Washington State Department of Ecology } \\ \text { EPA } & \text { Environmental Protection Agency } \\ \text { FQNW- } & \text { Ffuor Daniel Northwest } \\ \text { FFS } & \text { Fluor Federal Services } \\ \text { IPT } & \text { In-Plant-Training } \\ \text { JPM } & \text { Job Performance Measure } \\ \text { LMHC } & \text { Lockheed Martin Hanford Corporation } \\ \text { LOW } & \text { Liquid Observation We1ls } \\ \text { OE } & \text { Operations Engineer } \\ \text { OJT } & \text { On-The-Job Training } \\ \text { PIC } & \text { Person-In-Charge } \\ \text { RCRA } & \text { Resource Conservation \& Recovery Act } \\ \text { RPP } & \text { River Protection Project } \\ \text { SST } & \text { Single-Shell Tank } \\ \text { TMACS } & \text { Tank Monitoring and Control System } \\ \text { TSD } & \text { Treatment, Storage or Disposal Facility } \\ \text { WAC } & \text { Washington Administrative Code } \\ \text { WMH } & \text { Waste Management Federal Services of Hanford, Inc. }\end{array}$




\subsection{PURPOSE}

This document outlines the dangerous waste training program developed and implemented for a11, Treatment, Storage, and Disposal (TSD) Units operated by the tockeed Martin Hand River Protection Project (RPP) in the Hanford 200 East, 200 West and 600 Areas and the $<90$ Day AccumuTation Area at 209E. Operating TSD Units managed by RPP are: the DoubleShe11 Tank (DST) System, 204-AR Waste Unloading Facility, Grout, 600 Are Purgewater Storage-and the Effluent Treatment Facility (Operated-by-Waste Management Federal Services of Hanford, Inc.). TSQ Units undergoing closure are: - and the Single-She11 Tank (SST) System, 207-A South-Retention Basin, and the 216 B 63 Trench.

The program is designed in compliance with the requirements of Washington Administrative Code (WAC) 173-303-330 and Title 40 Code of Federal Regulations (CFR) 265:16 for the development of a written dangerous waste training program and the Hanford Facility Permit. Training requirements were determined by an assessment of employee duties and responsibilities.

The RPP training program is designed to prepare employees to operate and maintain the Tank Farms in a safe, effective, efficient, and environmentally sound manner. In addition to preparing employees to operate and maintain the Tank Farms under normal conditions, the training program ensures that employees are prepared to respond in a prompt and effective manner should abnormal or emergency conditions occur. Emergency response training is consistent with emergency responses outlined in the following Building Emergency P1 ans: HNF-IP-0263-TF and HNF-IP-0263-ETF.

\subsection{RESPONSIBILITIES}

The manager of each RPP waste management unit has overall responsibility for all training at the RPP units under their control. However, no one individual is designated as training director for the dangerous waste training program. The position is shared among RPP training, and support organizations. Each Tank Farm can access training resources and experts from many different areas on hazardous material, dangerous waste management, and safety rather than rely on the knowledge of one person. This shared responsibility ensures that the identification of appropriate training requirements and that the training program meets all applicable dangerous waste requirements.

2.1 RPP Responsibilities. Each RPP Unit Project manager has the following responsibilities related to training:

- Determine training requirements and training compliance for all Hanford Facility personnel, subcontractors and visitors who obtain access or work within RPP Units

- Request and/or conduct training

- Submit training completion records to RPP Training Records.

- Identify training requirements to contractors working in or around RPP Units. 
2.2 Training Organization Responsibilities. The Managers of Training Organizations have the following responsibilities:

- Ensure instructors have satisfactory instructional skills and are technically knowledgeable through: current qualification/ certification, or specialized training, or license/certificate, or degreed in the technical area, or other appropriate training or experience (see also DOE/RL-91-28 Chapter 8.0)

- Conduct informal job analysis and identify training commensurate with personnel duties and responsibilities

- Design and develop training programs

- Develop and instruct training courses

- Develop and maintain On-The-Job training requirements

- Maintain the RPP Training Records

2.3 Environmental Organization Responsibilities. The Environmental Organization has the following responsibilities:

- Consult with training organizations and RPP in the development and reevaluation of current training programs

- Assist RPP Project Managers in determining training requirements and RCRA compliánce for personnel

- Maintain current knowledge of RCRA training requirements pertaining to Hanford Facility Personnel.

2.4 Fluor Banie]-Nopthwest (FANW) Fluor Federal Services (FFS) and Waste Management Federal Services of Hanford, Inc. (WMH) Responsibilities. FDNW and WMH, whose personnel are classified as Hanford Facility Personnel, have the following responsibilities:

- Ensure that FFS and WMH employees are trained to meet RPP training requirements

- Maintain if requested by RPP.

\subsection{IMPLEMENTATION OF TRAINING PROGRAM}

The RPP Dangerous Waste training program is implemented. Incumbent personnel will complete new requirements within six months of the requirements being identified. Training of new employees is completed within the first six months of assignment. Training for personnel assigned to new positions is completed within six months of reassignment. Personnel who have not completed training are permitted to work at RPP only under the supervision of a trained employee. RPP operations management is responsible for ensuring that all personnel are trained and that required qualifications are maintained. 


\subsection{Identification of Training}

The required training is specified by the employee's specific job duties as determined by a management assessment or job analysis. The required training identified in Tables 4, 5, and 6 is based on worker categories and job tities described in Sections 4.0 and 5.0.

\subsection{Conduct of Training}

Training is provided through classroom instruction, On-the-Job Training (0JT), In-Plant Training (IPT), Computer-based training, and selfstudy. Training is instructed and/or developed by personnel knowledgeable in dangerous waste management procedures.

Following initial training, employees are required to have annual refresher training. Employees requiring qualification are required to recertify, as stated in the applicable program description for that job.

\subsection{Evaluation of Training}

RPP management reevaluates RPP training program courses at least every two years to ensure that dangerous waste training requirements continue to be met. Revisions to the RPP training program are based on facility or system modifications, procedure changes, DOE Orders, Federal and State regulatory requirements, industry operating experience and personnel performance evaluations.

\subsection{Documentation of Training}

Copies of the training record files for RPP dangerous waste management employees are stored at RPP Training and the originals are sent to the Hanford Training Center Records Department. A computerized copy is available at each of the Tank Farms for verification of training, qualification, or certification for RPP waste management. Training record copies, summaries for support organization employees and former employees (date of last worked at RPP), are kept and stored at the Hanford Training Center for three months. After three months, the training records are signed and dated and then transferred to the Records Holding Area. Once received at the Records Holding Area, the records are scanned and then held there for approximately one year. After approximately one year, the original training records are archived and sent to the Permanent Records Storage at the Federal Records Center in Seattle, Washington. The retention period there is 75 years. 


\subsection{DANGEROUS WASTE WORKER CATEGORIES}

Employee duties at RPP are categorized within six worker categories. In the event personnel duties and responsibilities overlap between categories, the employee will complete the training requirements for each category. These categories are:

1. A11 Employees

2. General Worker

3. Advanced General Worker

4. General Manager

5. General Shipper

6. Waste Designator

The duties corresponding to these categories are divided between "generator" and "TSD Unit-specific". job duties, each requiring varying degrees of dangerous waste management training. The description of job duties for each category can be matched to individual Job Titles or Job Positions commonly employed at the Hanford Facility. A description of the duties associated with each worker category is contained in Table 1. A description of dangerous waste training is contained in Table 2. Table 4 shows which programs are applicable for each worker category. 


\section{Table 1. Worker Categories}

\begin{tabular}{|c|c|c|}
\hline $\begin{array}{l}\text { WORKER } \\
\text { CATEGORIES } \\
\end{array}$ & $\begin{array}{l}\text { GENERATOR } \\
\text { JOB DUTIES } \\
\end{array}$ & $\begin{array}{l}\text { RPP UNIT SPECIFIC } \\
\text { JOB DUTIES }\end{array}$ \\
\hline ALL EMPLOYEES & $\begin{array}{l}\text { Is not categorized as a General } \\
\text { Worker, Advanced General Worker, } \\
\text { General Manager, General Shipper, or } \\
\text { Waste Designator. Will not manage } \\
\text { waste in accumulation containers on } \\
\text { the Hanford Facility. Responsible to } \\
\text { report spills and releases that they } \\
\text { discover. Must respond to specific } \\
\text { incidents which may occur. }\end{array}$ & $\begin{array}{l}\text { Duties are the same as for generator } \\
\text { job duties for all employees. }\end{array}$ \\
\hline GENERAL WORKER & $\begin{array}{l}\text { Generates dangerous waste and places } \\
\text { waste into appropriate containers. } \\
\text { Waste management activities are } \\
\text { overseen by person-in-charge or other } \\
\text { RPP unit personnel. Immediately } \\
\text { evacuate incident area and reports } \\
\text { incident to appropriate personnel: }\end{array}$ & $\begin{array}{l}\text { RPP unit specific duties might include } \\
\text { repair, replacement, calibration, } \\
\text { modification, or any other similar } \\
\text { activity on RPP unit systems. Wark } \\
\text { performed is either supervised by } \\
\text { qualified RPP personnel or is } \\
\text { adequately addressed through } \\
\text { organized pre-job briefing before } \\
\text { commencing work. Evacuate the RPP } \\
\text { unit during emergencies and notifies } \\
\text { appropriate personnel. }\end{array}$ \\
\hline $\begin{array}{l}\text { ADVANCED } \\
\text { GENERAL WORKER }\end{array}$ & $\begin{array}{l}\text { Duties exceed those of General } \\
\text { Workers for container management. } \\
\text { Inspects, marks, inventories, and } \\
\text { samples containers of dangerous } \\
\text { waste. Responds to spills and } \\
\text { releases according to approved } \\
\text { procedures. Performs daily } \\
\text { inspections or surveillances on tank } \\
\text { systems. }\end{array}$ & $\begin{array}{l}\text { RPP unit specific duties include the } \\
\text { control, operation, manipulation, } \\
\text { sampl ing, transfer or recording of } \\
\text { dangerous waste within containers, } \\
\text { tanks or waste process systems. } \\
\text { Includes abnormal operational } \\
\text { responses to maintain RPP units within } \\
\text { operational parameters. Implements } \\
\text { emergency procedures and responds to } \\
\text { spills according to approved. } \\
\text { procedures. }\end{array}$ \\
\hline GENERAL MANAGER & $\begin{array}{l}\text { Someone who can act as the } \\
\text { Environmental Compl iance officer, } \\
\text { Hazardous Material Special ist, or } \\
\text { directs Advanced General Workers in } \\
\text { dangerous waste management } \\
\text { activities. Responsible for the } \\
\text { accountability and directing of. } \\
\text { employees during dangerous waste } \\
\text { emergency events. }\end{array}$ & $\begin{array}{l}\text { Duties are the same for generator job } \\
\text { duties for Advanced General Worker. }\end{array}$ \\
\hline GENERAL. SHIPPER & $\begin{array}{l}\text { Signs paperwork relating to the } \\
\text { movement of dangerous waste } \\
\text { containers on roadways in compliance } \\
\text { with appl icable requirements. } \\
\text { Directs General and Advanced General } \\
\text { workers in transportation activities. }\end{array}$ & $\begin{array}{l}\text { Duties are the same for generator job } \\
\text { duties for General Shipper. }\end{array}$ \\
\hline WASTE DESIGNATOR & $\begin{array}{l}\text { Performs or completes waste } \\
\text { designations }\end{array}$ & $\begin{array}{l}\text { Duties are the same for generator job } \\
\text { duties for Waste Designator. }\end{array}$ \\
\hline
\end{tabular}


Table 2. DOE-RL Program Area Descriptions

\begin{tabular}{|c|c|}
\hline Program & Descriptions \\
\hline $\begin{array}{l}\text { Waste Management } \\
\text { Orientation }\end{array}$ & $\begin{array}{l}\text { Training in this program sub-area involves emergency responses, identifying contacts } \\
\text { for personnel to obtain dangerous waste management information, and waste minimization } \\
\text { concepts. Training also includes familiarization of the Hanford Facility Contingency } \\
\text { Plan (DOE/RL-93-75). }\end{array}$ \\
\hline $\begin{array}{l}\text { Unit/Bldg } \\
\text { Orientation }\end{array}$ & $\begin{array}{l}\text { This program sub-area provides unit/building specific information on the hazards in } \\
\text { the immediate and surrounding work environments. This training will ensure personnel } \\
\text { are informed about potential emergency at a unit/building to which access is desired. }\end{array}$ \\
\hline $\begin{array}{l}\text { Waste Management } \\
\text { Awareness }\end{array}$ & $\begin{array}{l}\text { The sub-area in. this program addresses the generation of waste, segregating the waste, } \\
\text { and placing the waste into pre-approved containers. The training provides a } \\
\text { discussion on what the initial accumulation container is titled and the management } \\
\text { requirements that pertain, proper responses to incidents pertaining to the initial } \\
\text { accumulation containers, proper responses to deal ing with waste of unknown origins, } \\
\text { and proper responses to questions posed by a regulatory agency inspector concerning } \\
\text { these elements. General safe practices for handling and storing dangerous } \\
\text { waste/materials are addressed. }\end{array}$ \\
\hline $\begin{array}{l}\text { Unit/Bldg } \\
\text { Awareness }\end{array}$ & $\begin{array}{l}\text { This program sub-area encompasses the job-specific or building-specific requirements } \\
\text { that supplement the information provided in waste management awareness general sub- } \\
\text { area. The training provides personnel at each unique unit/building with proper waste } \\
\text { handling and emergency procedures relevant to their responsibilities during normal } \\
\text { operations and emergencies. }\end{array}$ \\
\hline $\begin{array}{l}\text { Waste } \\
\text { Management } \\
\text { Advanced }\end{array}$ & $\begin{array}{l}\text { The training within this sub-area is for unit/building personnel who must ensure that } \\
\text { the waste management unit is operating in accordance with approved procedures and } \\
\text { appl icable regulations. General advanced training is provided only for container } \\
\text { management. Training for other RCRA units such as tank systems, surface impoundments, } \\
\text { landfills, etc., must be covered through the unit/building specific portion of the } \\
\text { advanced program. }\end{array}$ \\
\hline Unit/Bldg Advanced & $\begin{array}{l}\text { This sub-area provides specific information required to operate, control, and manage } \\
\text { processes and dangerous waste management operations. For container management, the } \\
\text { unit/building specific program supplements the information provided in the general } \\
\text { training within this program area. Considerations for this program involve container } \\
\text { management as well as all advanced program area training for other RCRA units such as } \\
\text { tank systems, surface impoundments, landfills, etc. This program can be met or } \\
\text { partially met by the unit/job specific program area if operator and supervisor/manager } \\
\text { qualification programs must be administered. }\end{array}$ \\
\hline $\begin{array}{l}\text { Waste } \\
\text { Management } \\
\text { Administration }\end{array}$ & $\begin{array}{l}\text { This program area covers administrative aspects such as document preparation for plans } \\
\text { and procedures relating to environmental reporting, waste minimization, and waste } \\
\text { management. It also covers sampling and analysis considerations to aid in the } \\
\text { development of sampling and analysis plans, waste analysis plans and waste } \\
\text { designations. }\end{array}$ \\
\hline $\begin{array}{l}\text { Unit/Job } \\
\text { Specific }\end{array}$ & $\begin{array}{l}\text { Training within this program area constitutes one of the tools used in developing a } \\
\text { compliant unit/building specific training program and is based on compliance with DOE } \\
\text { Order } 5480.20 \mathrm{~A} \text {. It is designed to provide additional information to ensure the safe } \\
\text { and efficient operation and maintenance of unit processes, and does not apply to all } \\
\text { unit/buildings on the Hanford Facility. Additionally, the training provides more } \\
\text { detailed information for the response to emergencies and abnormal events that could } \\
\text { occur. Not all training within this program will be RCRA related. Some operator or. } \\
\text { supervisor/manager qualification programs are not based on dangerous waste managenent. }\end{array}$ \\
\hline
\end{tabular}

NOTE:

Double line indicates split in program areas 


\subsection{JOB POSITIONS AND DESCRIPTIONS}

Each employee is assigned a job title (from salaried nonexempt or bargaining unit classifications) or position (from exempt classifications). Job or position descriptions include requisite skills, work experience, education, and other qualifications, and a list of duties and/or responsibilities for each job title or position. The work experience, education, and other qualifications required for each position are maintained by Human Resources. As a minimum, all employees require a high school diploma or equivalent. Personnel filling exempt, management or engineering positions normally require a college degree with 2 or more years of industry experience.

In the following sections, brief job titles and position descriptions of employees associated with dangerous waste management at RPP are listed within the appropriate worker category.

\subsection{Al1 Employees}

Hanford Facility personnel included in this category are not categorized into one of the other five.worker categories. Visitors and subcontractors included within this category are those personnel not categorized as General Workers and that require access to portions of the RPP Facilities not accessible to the public. Personnel in this category will not perform duties or responsibilities associated with the management of waste in accumulation containers or with the critical system of the RPP unit. All personnel have the responsibility to report spills and releases that they discover in addition to evacuation or take cover actions in response to specific incidents.

Most Hanford Facility personnel categorized as "Al1 Employees" are administrative personne] such as secretaries, clerks and support organizations who tour or provide oversight. Most visitors will be categorized as All Employees since visitors generally tour, provide oversight, or are brought on the Hanford Facility for interviews. Subcontractors who gain access to the RPP Facilities to complete work in controlled areas, which does not involve the management of dangerous or mixed waste, will be categorized as All Employees.

\subsection{General Worker}

Hanford Facility personnel or subcontractors with waste management duties and responsibilities limited to the initial generation of waste and placing that waste into a pre-approved containers are classified as General Workers. These personnel could generate dangerous or mixed waste while working on a non-RCRA system (e.g., building maintenance) or on a TSD unit conducting maintenance or modification on critical or non-critical systems. The term "critical system" is defined in the Hanford Facility RCRA Permit. The work may be unsupervised or completed under the supervision of a Person-In-Charge (PIC) or unit/building personnel.

Hanford Facility personnel categorized as General Workers may be assigned duties and responsibilities for: (1) placing waste they generate into preapproved containers and filling out log sheets where applicable, (2) completing radiological surveys of dangerous or mixed waste, (3) the loading of packaged containers onto trucks or movement of containers where a spill or 
release may occur, and (4) responding to regulatory agency compliance inspectors questions about satellite accumulation area management practices. Personnel who function as General Workers may include, but are not 1 imited to, the following:

- Maintenance personnel

- Health physics technicians

- Subcontractor supervisors of general workers

- Transporters

- Contractor crafts

- Ecology personnel acquiring samples of dangerous or mixed waste

\subsection{Advanced General Worker}

Hanford Facility personnel are categorized as Advanced General Workers if their duties and responsibilities concerning dangerous or mixed waste exceed that of General Workers. Nuclear Chemical Operators are typically Advanced General Workers. Examples of these duties and responsibilities for container management can include: inspecting containers, applying advanced container markings and preparing container log sheets, completing waste inventories, sampling of waste, and responding to spills and releases according to approved procedures.

For RPP RCRA TSD units, Hanford Facility personnel assigned duties and responsibilities associated with ensuring the compliant operation of that TSD unit will be categorized as Advanced General Workers. Their duties and responsibilities may include, but are not 1 imited to: operators who conduct daily inspections on tank systems to ensure they are operating properly and operators who conduct daily inspections on tank system ancillary equipment that is not provided with secondary containment and receiving shipments of waste. In these cases, the operator must perform an evaluation whether the TSD unit is functioning properly and operating in compliance with WAC 173-303. These personnel typically have the responsibility to act and/or notify RPP operations management when an incident occurs that requires immediate response, such as a leaking or deteriorating container, spill or release, or process upset. Table 3 lists which TSD facilities utilize the Advanced General Workers. The 1 ist of employees currently filling these positions is maintained by HNF-IP-0974 or equivalent electronic system(s). 


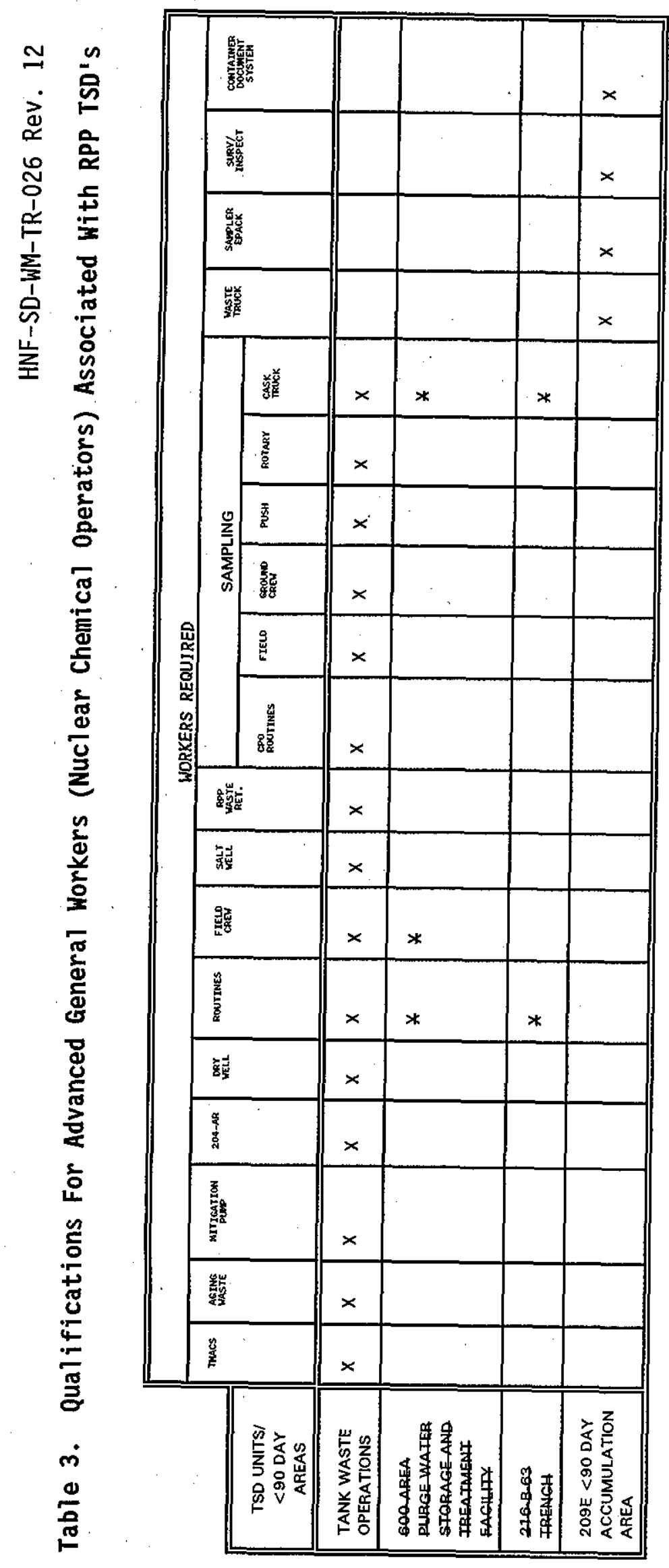


5.3.1 TMACS Operators. Responsibilities and duties include:

- Operate the TMACS Central Facility

- Review reports generated by the Tank Monitoring and Control System (TMACS)

- Inform supervisors of abnormal conditions in SSTs and DSTs reported by the TMACS.

5.3.2 Aging Waste Operators. Responsibilities and duties include:

- Perform Aging Waste Facilities work activities in accordance with current operating procedures

- Perform sampling as required by procedure

- Operate process equipment associated with the Aging Waste Facilities

- Provide surveillance of the Aging Waste Facilities for abnormal conditions

- Respond to alarms at the Aging Waste Facilities

- Respond to abnormal and/or emergency conditions according to established procedures

- Respond to dangerous waste leaks or spills

- Perform routine inspections of the Aging Waste Facilities (241-AY and 241-AZ Tank Farms).

\subsubsection{Mitigation Pump Operators. Responsibilities and duties} include:

- Perform mitigation pump work activities in accordance with current operating procedures

- Operate mitigation pump processes, systems, and equipment at the Tank Farms

- Conduct routine inspections

- Provide surveillance of the Tank Farms for abnormal conditions

- Respond to alarms at the Tank Farms

- Respond to abnormal and/or emergency conditions according to established procedures. 


\subsubsection{4-AR Building Operators. Responsibilities and duties include:}

- Perform 204-AR Building work activities in accordance with current operating procedures

- Operate processes, systems, and equipment at the 204-AR Building

- Perform sampling as required by procedure

- Conduct routine inspections

- Provide surveillance of the 204-AR Building for abnormal conditions

- Respond to alarms at the 204-AR Building

- Respond to abnormal and/or emergency conditions according to established procedures

- Respond to dangerous waste leaks or spills

- Transfer waste from tankers to DSTs

- Transfer waste from rail cars to DSTs

- Treat waste transferred to DSTs to maintain operating specifications. 5.3.5 Drywe11 Operators. Responsibilities and duties include:

- Perform Drywell Van work activities in the Tank Farms in accordance with current operating procedures

- Perform In-Tank Photography and Video Taping in accordance with current operating procedures

- Operate the Drywell Van and support systems used to monitor Drywells, Liquid Observation Wells (LOW) and Laterals.

5.3.6 Routines Operators. Responsibilities and duties include:

- Perform Tank Farm work activities in accordance with current operating procedures

- Operate processes, systems, and equipment at the Tank Farms

- Perform sampling as required by procedure

- Conduct routine inspections

- Provide surveillance of the Tank Farms for abnormal conditions

- Respond to alarms at the Tank Farms

- Respond to abnormal and/or emergency conditions according to established procedures 
- Respond to dangerous waste leaks or spills

- Escort supporting crafts and visitors entering the Tank Farm areas as required.

5.3.7 Field Crew 0perators. Responsibilities and duties include:

- Perform Tank Farm work activities in accordance with current operating procedures

- Perform sampling as required by procedure

- Conduct routine inspections

- Respond to alarms at the Tank Farms

- Respond to abnorma1 and/or emergency conditions according to established procedures

- Respond to dangerous waste leaks or spills

- Perform waste transfer routing changes

- Perform pipeline pressure tests

- Perform equipment installation and removal

- Perform tank Tancing operations.

5.3.8 Saltwell Operators. Responsibilities and duties include:

- Operate the jet pumps to transfer waste from SSTs to DSTS

- Perform Saltwell work activities in accordance with current operating procedures, including data collection

- Perform sampling as required by procedure

- Conduct routine inspections of Saltwell systems

- Respond to and trouble shoot Saltwell alarms

- Respond to abnormal and/or emergency conditions according to estäblished procedures

- Respond to dangerous waste leaks or spit1s.

5.3.9 RPP Waste Retrieval. Responsibilities and duties include:

- Start-up; operate, and shutdown of the Sluicing System

- Operate the Data Acquisition System

- Operate the WRSS Raw Water System

- Know the BIO/TSR/LCO/AC's associated with S7uicing 
- Wear an SCBA

- Start-up, operate, and shutdown the WRSS 296-C-006 HVAC System

- Respond to alarms and abnormal conditions

5.3.10 Field Sampling Operators. Responsibilities and duties include:

- Perform liquid and vapor sampling of SSTs and DSTs as required by procedure.

- Support laboratory personnel in the performance of sampling as required by procedure.

- Perform auger sampling of SSTs and DSTs as required by procedure.

- Perform Tank Farm work activities in accordance with current operating procedures

- Respond to abnormal and/or emergency conditions according to establ ished procedures

- Respond to dangerous waste leaks or spills.

\subsubsection{Core Sampling Operators.}

\subsubsection{Ground Crew Operator Responsibilities and duties} include:

- Perform Tank Farm work activities in accordance with current operating procedures

- Respond to abnormal and/or emergency conditions according to established procedures

- Respond to dangerous waste leaks or spills

- Perform ground activities in support of the core sampling trucks and systems, either Rotary Mode or Push Mode, as required by procedure, to take samples of the waste tank core layers.

\subsubsection{Push Mode Operator: Responsibilities and duties include:}

- Perform Tank Farm work activities in accordance with current operating procedures

- Respond to abnormal and/or emergency conditions according to established procedures

- Respond to dangerous waste leaks or spills

- Operate the core sampling trucks and systems in Push Mode, as required by procedure, to take samples of the waste tank core Tayers. 


\subsubsection{Rotary Mode Operator: Responsibilities and duties} include:

- Perform Tank Farm work activities in accordance with current operating procedures

- Respond to abnormal and/or emergency conditions according to established procedures

- Respond to dangerous waste leaks or spilis

- Operate the core sampling trucks and systems in Rotary Mode, as required by procedure, to take samples of the waste tank core layers.

\subsubsection{Cask/Sample Truck Operators: Responsibilities and duties} include:

- Perform Cask/Sample truck work activities in accordance with current operating procedures

- Pick-up and transport samples to the laboratories

- Respond to accidents involving Cask/Sample truck.

5.3.12A Characterization Project Routines Operator: Responsibilities and duties include:

- Perform Tank Farm work activities in accordance with current operating procedures

- Respond to abnormal and/or emergency conditions according to established procedures.

- Respond to dangerous waste leaks or spills

- Perform In-Tank Photography and Video Taping in accordance with current operating procedures

- Perform prepatory work for sampling activities in accordance with current operating procedures.

\subsubsection{Solid Waste-Project - Waste-Operations Truck Operators} Responsibilities and duties-inelude:

- Ensure that vehieles transponting dangerous wastes are up to date on

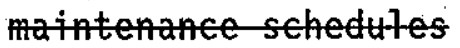

- Prepare-containers to receive mixed-and dangerous waste

- Beliver and collect waste-containers from Satellite-Aceumlation Areas and waste generators

- Setup-Satellite-Accumulation Areas

- Untoad trucks at the- 90 -day acemulation area 
- Ensure that trucks transporting dangerous waste-are-placarded properly

- Ensure that the waste has been properfy secured in the transportation vehicles:

\subsubsection{4-Solid-Waste-Project - Waste-Opepations Sampling/Repacking} operators. Responsibilities and duties include:

- Package and label dangerous waste for-shipment from the $\mathrm{Q} 90$ day aeetmutation area

- Perform sampling as require by procedure at the s9o day accumutation areat

- Suppont laboratory personnel in the performance-of sampling as required by procedure at the $<90$ day aceumulation area

- Prepare containers to receive-mixed and dangerous waste

- Escort-supporting erafts and visitors entering the- 490 day aceumulation area as required

- Receive, segregate, sort, inventory, store, and-stage dangerous waste

- Operate processes, systems, and equipment at the 490 day accumllation area

- Respond to alarms at the- 20 -day accumulation area

- Respond to abnomal and/or emergency conditions according to established procedures

- Respond to dangerous waste- leaks op spills.

5.3.15-Solid Waste Project - Waste-Operations Containep Document System-operators. Responsibitities and duties include:

- Maintain tracking records for dangerous and mixed wate containers

- Complete shipping documentation-for dangerous and mixed waste eontainers

- Develop container tracking folders.

¿-5.3.16 Solid Waste-Project-Waste-Operations-Surveillance/Inspection operators. Responsibilities and duties include:

- Perform $<90$ day accumtation area work activities in accordance-with euprent operating procedures

- Escort-supporting erafts and visitors entering the 490 day acemflation area as required

- Receive, segregate, sort, inventory, store, and-stage dangerous-waste 


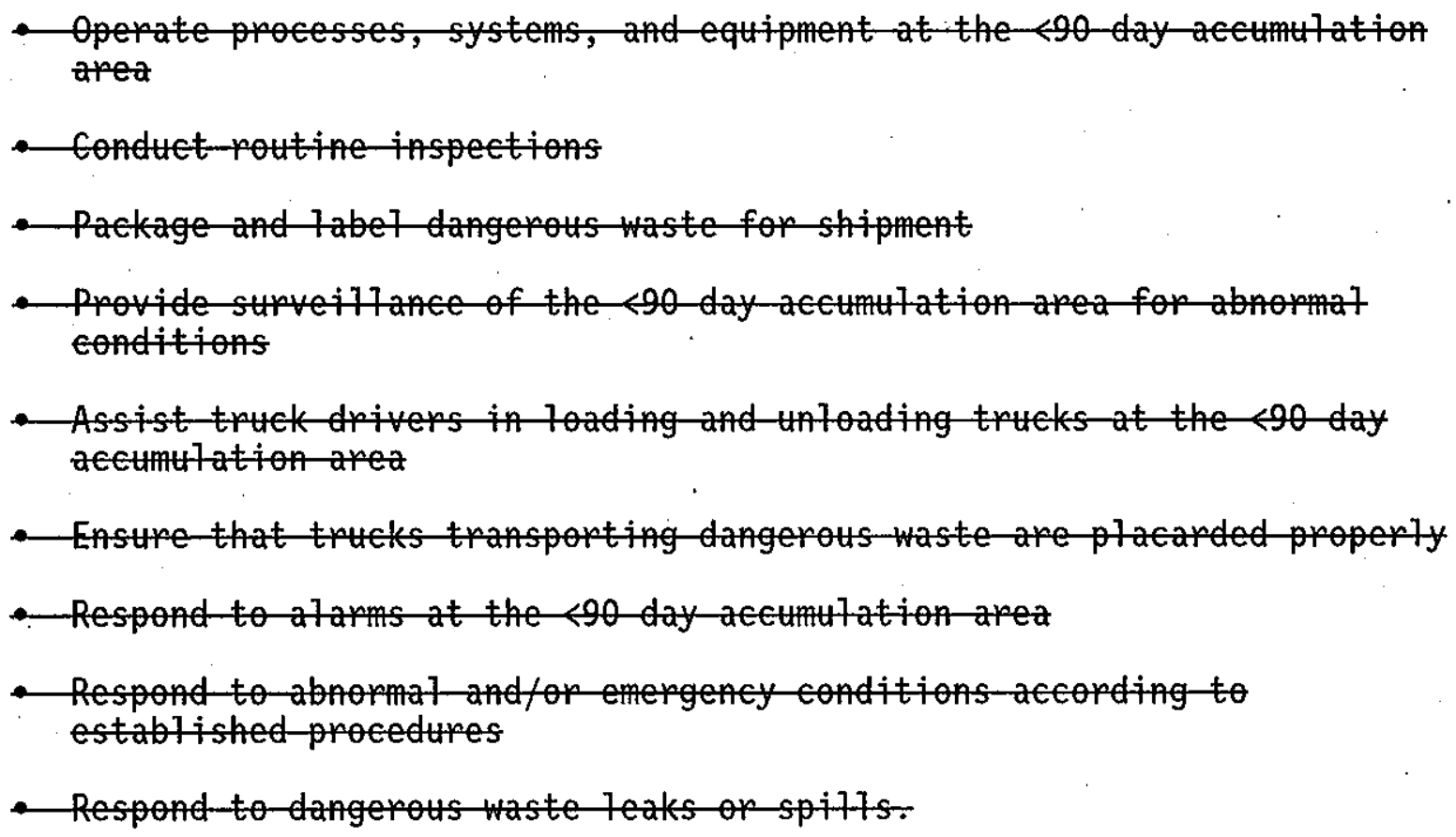

\subsection{General Manager}

Various types of managers are included in this position. In addition, RPP. personnel may be categorized as General Managers if they direct General Worker or Advanced General Worker activities. Managers and those who direct General Workers and Advanced General Workers have many similar duties and responsibilities relating to dangerous or mixed waste management and are required to take the same courses.

The following managers are included within this position:

(1) RPP Environmental Compliance Officer

(2) RPP Operations Shift Managers and Operations Engineers

(3) RPP Operations Support Managers

(4) RPP Qualified Person-In-Charge (PIC)

(5) Solid Waste Project Waste Operations-Manager

(6) Solid Waste Project Waste operations Person In Charge (PIC)

(7) RPP Hazardous Material Specialist

The list of employees currently filling these positions is maintained by HNF-IP-0974 or equivelent electronic system(s).

5.4.1 RPP Environmental Compliance Officer. Responsibilities of the Environmental Compliance officer include the following:

- Provide support to RPP unit management to ensure compliance with the applicable environmental compliance requirements as identified in this manual, environmental permits, the Hanford Federal Facility Agreement and Consent Order, HNF-CM-7-5, Tank Farm S/RIDS and other compliance orders

- Ensure that RPP unit management is aware of the unit's environmental compliance status and the unit's environmental compliance activities 
- Understand and be able to explain the RPP unit's environmental compliance status with all applicable environmental requirements

- Advise the RPP unit management of new environmental requirements and policies, the associated impacts, and recommended implementation mechanisms to ensure compliance.

\subsubsection{RPP Shift Operations Managers and Operations Engineers. Responsibilities of the RPP Operations Shift Operations, Operations Engineers include the following:}

- Supervise, coordinate, and direct the activities in the Tank Farms

- Ensure that RPP operations are conducted in accordance with established operating procedures and policies, U.S. Department of Energy Orders, and Federal and State regulations

- Supervise and coordinate the receipt, storage, transfer, and reprocessing of dangerous waste

- Ensure compliance with RPP operating limits and specifications

- Conduct pre-job safety and planning meetings with personnel involved with Tank Farms operations as applicable

- Maintain operating records

- Revise and review RPP operating procedures as applicable

- Recognize abnormal conditions and take appropriate action

- Respond to abnormal and/or emergency conditions according to established procedures

- Notify RPP management of any unplanned releases to the environment

- Serve as the building emergency director (BED), the staging area manager or designated alternate BED, as assigned

- Perform the duties of the building emergency director, as assigned, for the Tank Farms during emergencies.

5.4.3 RPP Operations Support Managers. Line Management within the RPP Operations Organization provides support as applicable to ensure the safe, effective, efficient, and environmentally acceptable operation of RPP facilities and systems. This operation is in accordance with applicable dangerous waste management procedures, U.S. Department of Energy Directives, applicable management policies, and Federal and State regulations. Responsibilities of the RPP support organizations management and technical support personnel include, but are not limited to, the following functions:

- Maintenance

- Production Control

- Recovery Support

- Isolation/Stabilization

- Waste Retrieval 
- Vapor, Liquid and Core Sampling.
5.4.4 RPP Qualified Person-In-Charge (PIC). Responsibilities and duties include:

- Coordinate and direct the activities of Advanced General Workers in the completion of field activities

- Review procedures to assure that they are adequate to perform and control the tasks.

- Ensure work is performed in compliance with environmental regulations and permits through adherence to procedures and control manuals.

\subsubsection{Solid Waste Project. Waste Operations Manager. Responsibilities and duties-include:}

- Supervise, coordinate, and-dipect the ativities of Solid-Waste Operations Team terders

- Maintain control over $<0$ day accumlation-area operations in accordance with-established operating procedures and policies, U.S. Department-of Energy Orders, and State, and Federal regutations

- Dipect, control, and coordinate the receipt, storage, transfer, and processing of dangerous waste

- Ensure 490 day accumulation area operations are conducted-aecording to establitshed procedures

- Ensure compliance-with- 90 day accumlation-area operating limits-and specifications

- Ensure that job-safety and planning meetings-are-conducted, as applicable, with personnel involved with the 290 day aceumltation area operations

- Ensure that regutatony-reconds are maintained

- Develop, revise, and review-90 day accumlation-area operating procedupes-as applicable

- Respond to and provide remedial guidance and decisions for operationat anomalies, abnormat conditions, and equipment malfunctions

- Respond to-abnormal and/or emergency-conditions according-to. established-procedures

- Coopdinate the recovery from-unplanned reteases to the-environment and other emergenty-conditions. 


\subsubsection{Solid Waste-Project Waste-Operations Person-In-Charge (PIC).} Responsibilities and duties include:

- Stpervise, coordinate, and direct the activities of the solid llaste Operators

- Ensure-that 490 day acemulation area operations are in accordance with operating-proeedures and policies, U.S. Department of Energy Orders, State, and Federal regulations

- Supervise and coordinate the peceipt, storage, transfer, and reprocessing of dangerous waste

- Conduct 290 -day aceumulation area operations acconding to established procedures.

- Ensure compliance-with- 490 day accumllation area operating-limits and specifications

- Conduct pre job safety-and-planning meetings (Job specific-Training) with-personnel involved with $<90$-day aceumulation area operations as applieable

- Maintain regutatory records

- Revise and review 40 day accumtation apea-operating procedures as appliteable

- Recognize abnomal-conditions and take appropniate-actions-

- Respond-to-abnomal or emergency conditions acconding to established procedures

- Not ify 20 -day acemmlation area management-of any unplanned releases

- Ensure that vehicles transpopting dangerous wastes are curpent-on maintenance-schedutes

- Enstrre-that waste has been properly sectred-in transpontation vehictes.

5.4.7 RPP Hazardous Material Specialist. Responsibilities and duties include:

- Create and maintain satellite accumulation areas for maintenance of waste generated in non-radiologically controlled areas in compliance with applicable requirements

- Interface with other organizations as needed to ensure proper disposal of wastes

- Prepare and maintain documents required by Federal and State regulations and $\mathrm{LMHC}$ policies

- Ensure non-regulated alternatives are used whenever possible by reviewing purchase requisitions for chemical products 
HNF-SD-WM-TR-026 Rev. 12

- Provide review and waste disposition instructions on the waste planning checklist as required

- Recognize abnormal conditions and take appropriate action

- Respond to abnormal or emergency conditions according to established procedures

- Ensure that the waste has been properly secured in the transportation vehicles.

\subsection{General Shipper}

Personnel who sign waste movement documentation for both onsite and off-site shipments of dangerous or mixed waste on roadways are categorized as General Shippers in the RCRA training program. There is no distinction within this category based upon where a dangerous or mixed waste movement will initiate, terminate, or which road the movement will travel along. The 1 ist of employees currently filling this position is maintained by HNF-IP-0974 or equivalent electronic system(s).

\subsection{Waste Designator}

Personnel who perform and/or complete waste designations at RPP waste management units are categorized as a Waste Designator. The 1ist of employees currently filling this position is maintained by HNF-IP-0974 or equivalent electronic system(s).

\subsection{TRAINING CONTENT, FREQUENCY, AND TECHNIQUES}

This section provides an overview of dangerous waste management and jobspecific training provided to employees in job titles and positions discussed in the previous sections. In addition to RPP normal operating conditions, employees are trained on emergency equipment, systems, and procedures to include the following, where applicable:

- Procedures for using, inspecting, repairing and replacing RPP emergency and monitoring equipment

- Automatic or manual dangerous waste feed cut-off systems

- Communications and alarm systems

- Response to fires and explosions

- Response to dangerous waste contamination incidents and spills

- Shutdown of operations.

The training program uses existing courses with content ranging from general to specific dangerous waste training material. Initial and continuing training program requirements are listed in Table 4 for each worker category. Appendix A-1 contains a brief description of the training courses for this program, including course title, course description, target audience, instructional delivery, evaluation method, length of course, and frequency of retraining. 
The RPP-specific and job-specific qualifications and/or certifications are maintained according to contractual and regulatory requirements. Courses are provided through classroom instruction, on-the-job training, in-planttraining, self-study, and computer-based training and addresses the RPP management procedures, U.S. Department of Energy directives, applicable management policies, and Federal and State regulatory requirements. The training includes instruction on the implementation of the Tank Farms contingency plan (Building Emergency Plan) and use of emergency and monitoring equipment. The RPP nuclear operators and shift operations managers are certified for assigned jobs through a performance-based training process.

The RPP support organizations employees are also required to complete identified RPP training applicable to their involvement with dangerous waste management. The RPP support organizations management is responsible for identifying individual employee training requirements in accordance with this plan and for ensuring that training requirements are met.

The RPP initial and continuing training program job-specific course requirements relating to dangerous waste management are listed in Tables 5 and 6 . Appendix A-2 contains a brief description of the training courses for this program, including course title, course description, target audience, instructional delivery, evaluation method, length of course, and frequency of retraining.

\subsection{Relevance of Training to Job Positions}

The dangerous waste training program for RPP employees was developed after reviewing U.S. Department of Energy directives, Federal and State regulations, and the completion of a job analysis for management-selected job positions. Tasks performed by employees were identified and evaluated to determine training requirements. In addition, training needs are evaluated continually in relation to current U.S. Department of Energy directives and Federal and State regulations.

Qualification for Shift Operations Managers, Nuclear Operators and Nuclear Chemical Operators are required by U.S. Department of Energy Order 5480.20A. Qualification for General Shippers is required by LMHC policy. To become certified, an employee must successfully complete classroom training, self-study, and on-the-job training, as applicable. Classroom instruction and/or self-study is designed to provide qualification candidates with the fundamental knowledge required to work safely at RPP.

The RPP Dangerous Waste training program outlined here ensures that a11 personnel entering the Tank Farms are trained properly to perform the job duties pertinent to the handling, treatment, storage, and/or disposal of dangerous waste.

RPP employees and support organization employees also receive additional training in accordance with other regulations such as 29 CFR 1910.120, "Hazardous Waste Operations and Emergency Response" and 29 CFR 1910.1200, "Hazard Communication Program," and the U.S. Department of Energy directives and management policies including "Environmental Regulations at Hanford". These courses are not discussed in this training plan. 


\subsection{Training to Emergency Response}

Federal and State regulations require that employees be able to respond effectively to emergencies and that employees be familiar with emergency procedures, emergency equipment, and emergency systems. Specific topics required by Federal and State dangerous waste regulations listed in Section 6.0 are addressed throughout the Dangerous Waste training program and are included in the following training:

- New Employee Safety Orientation

- Hanford General Employee Training

- Tank Farms Facility Orientation

- Generator Hazards Safety Training

- Facility Emergency and Hazard Information Checklist

- RPP Nuclear Operator and Manager qualification training

- Building Emergency Director training.

\subsection{Waste Management Orientation}

All employees are required to complete Waste Management Orientation (see Table 4) training, which includes Site emergency response training. The training at this level involves a basic introduction to dangerous waste management. It addresses correct response to emergencies involving releases of materials to the environment. It includes a discussion of the "Hanford Facility" and permits for TSDs along with additional training requirements should employee dangerous waste management duties change.

Tank Farms orientation is provided for personnel who require access to a RPP TSD Unit/Building. Training is conducted for the Tank Farms Emergency Signals and appropriate responses.

\subsection{Waste Management Awareness}

In addition to Waste Management Orientation, Waste Management Awareness (Waste Handling, Segregation \& Packaging course 350560 is equivalent) (see Table 4) training is required for general workers, advanced general workers, general managers, and general shippers. The training at this level is commensurate with the duties of generating waste and $\mathrm{placing}$ into pre-approved containers. The training addresses the identification, packaging, marking and labeling and proper handling of dangerous wastes including the regulatory requirements for accumulation and storage. Additionally, the training covers contingency plan requirements and worker response to small spills, materials release reporting, and notifications. General safe practices for handling, storing and transporting dangerous waste materials are addressed.

Unit/Building-specific training is also provided. This portion of the training encompasses the job-specific or building-specific requirements that supplement the information provided in waste management awareness. The training provides employees with proper waste handling and emergency procedures relevant to their responsibilities during normal facility operations and emergencies.

\subsection{Waste Management Advanced}

In addition to Waste Management Orientation and Waste Management Awareness, general managers, general shippers, and Environmental Waste 
Operators must complete Waste Management Advanced (see Table 4) training. General managers complete training on environmental regulations and/or environmental compliance. The training includes information on potential legal liabilities, applicable Federal and State regulations, various reporting requirements, inspections/audits and record keeping. General shippers Solid-Waste operators complete containerized waste management training. The training is for facility personnel who properly select, package and prepare for shipment containers of dangerous wastes. This is a comprehensive container waste management training program and provides the necessary information regarding documentation, reporting, record keeping, and other information pertaining to administrative functions of dangerous waste management.

\subsection{Waste Management Administration}

Waste Management Administration is for general shippers, waste designators and those who must resolve problems and issues related to dangerous waste management. This training covers administration aspects of waste minimization, waste management, and record keeping for the Hanford Facility.

\subsection{Qualification Training}

In addition to Waste Management Orientation and Waste Management Awareness; nuclear operators and Shift Operations Managers complete specific courses in preparation for work assignments. Qualifications for job-specific work assignments have been developed in accordance with U.S. Department of Energy Order 5480.20A. The training at this level is designed to provide indepth facility knowledge to ensure the safe and efficient operation of RPP processes and operations. Additionally, qualification training provides detailed information for the response to emergencies and abnormal events which could occur within the unit. Once certified, employees are required to recertify biennially through continuing training classes, self study and completion of an examination.

\subsection{Subcontractor Training and Visitor Training.}

Subcontractor personnel and visitors at RPP must complete the appropriate level of training determined by RPP management according to their job duties.

Personnel who have completed training off-site are required to provide a certificate or other suitable evidence of training course(s) that meet the requirements of WAC 173-303 and this plan. The RPP Project Manager must verify the acceptability of off-site training as commensurate with subcontractor personnel's anticipated RPP job assignment and the training requirements listed in Table 4 .

RPP Management is responsible for ensuring that subcontractor personnel and visitor medical surveil1ance requirements are met before granting access to the Tank Farms. RPP management is responsible for ensuring that all the requirements for access to the Tank Farms are met. 


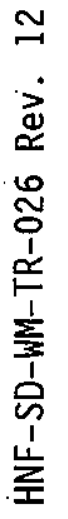

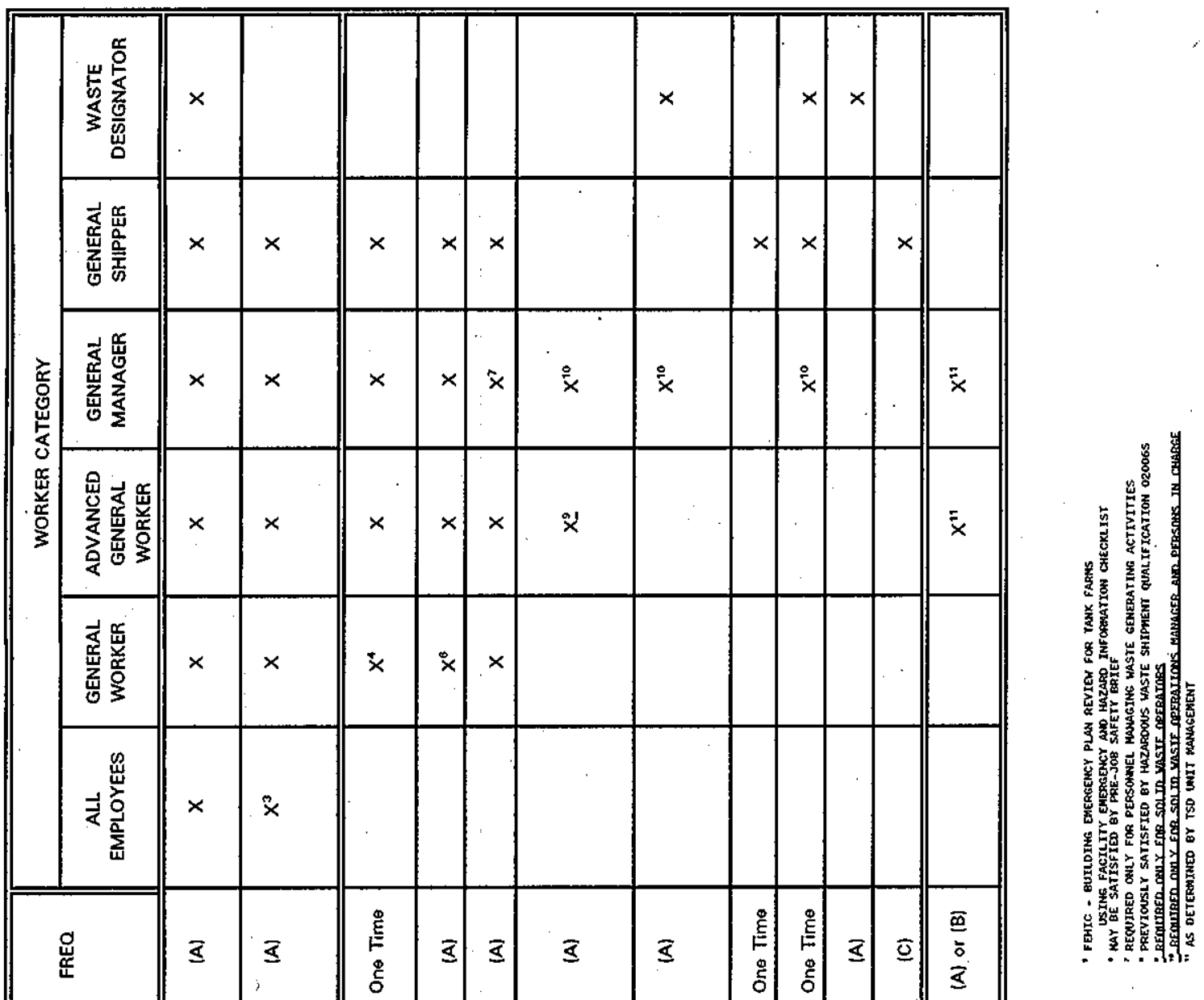




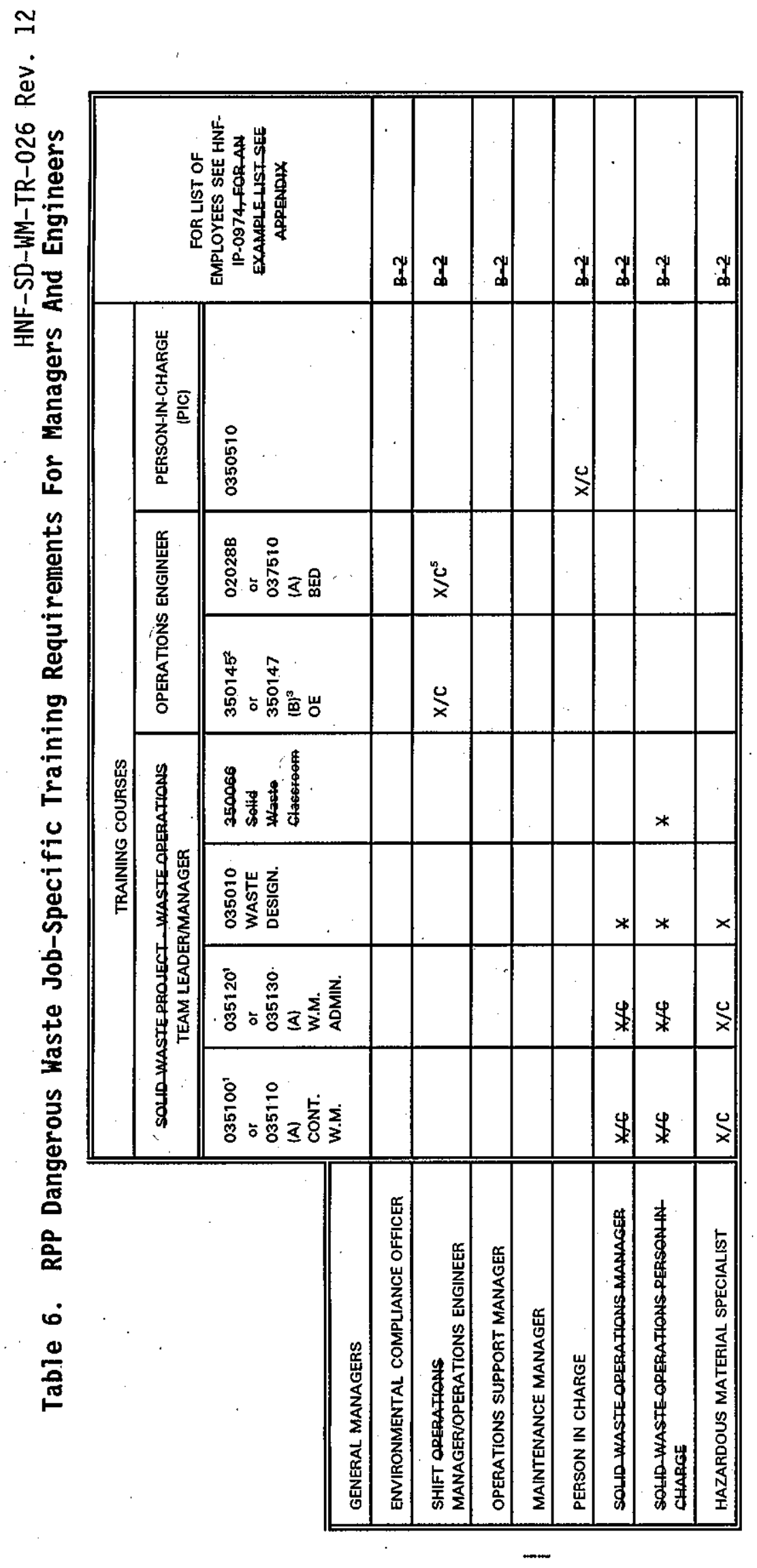

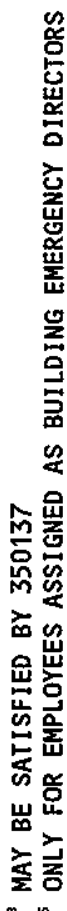

总

焉高

을

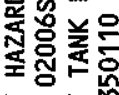

亩不就

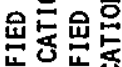

彭总

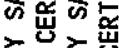

要㤩

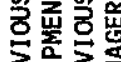

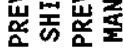

立

方虽

요요은

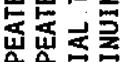

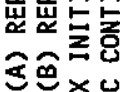


Table 7. Courses for Tables 4,5 and 6

\section{CURRENT COURSES DESCRIBED IN APPENDIX A}

\begin{tabular}{|c|c|}
\hline $\begin{array}{l}000001 \\
000090 \\
02006 \mathrm{G} \\
020159 \\
02028 \mathrm{~B} \\
035010 \\
035012 \\
035020 \\
035100 \\
035110 \\
035120 \\
035130 \\
037510 \\
03 \mathrm{E} 060 \\
350010 \\
350020 \\
350030 \\
350031 \\
350035 \\
350037 \\
350040 \\
350060 \\
350066 \\
350070 \\
350075 \\
350077 \\
350080 \\
350090 \\
350100 \\
350145 \\
350165\end{array}$ & $\begin{array}{l}\text { Visitor/Vendor Orientation } \\
\text { Waste Management Awareness } \\
\text { Hazardous Waste Shipper Qualification - Advanced Course 2 } \\
\text { Building Emergency Director Training } \\
\text { Waste Designation. } \\
\text { Waste Designation Qualification } \\
\text { Facility Waste Sampling and Analysis } \\
\text { Container Waste Management - Initial } \\
\text { Container Waste Management - Refresher } \\
\text { Waste Management Administrative - Initial } \\
\text { Waste Management Administrative - Refresher } \\
\text { Building Emergency Director/Building Warden - Requalification } \\
\text { Building Emergency Plan Review using the Facility Emergency and } \\
\text { Hazard Information Checklist for Tank Farms } \\
\text { Solid Waste-Project Waste-Operations-Truck-Operations Initiat }\end{array}$ \\
\hline
\end{tabular}




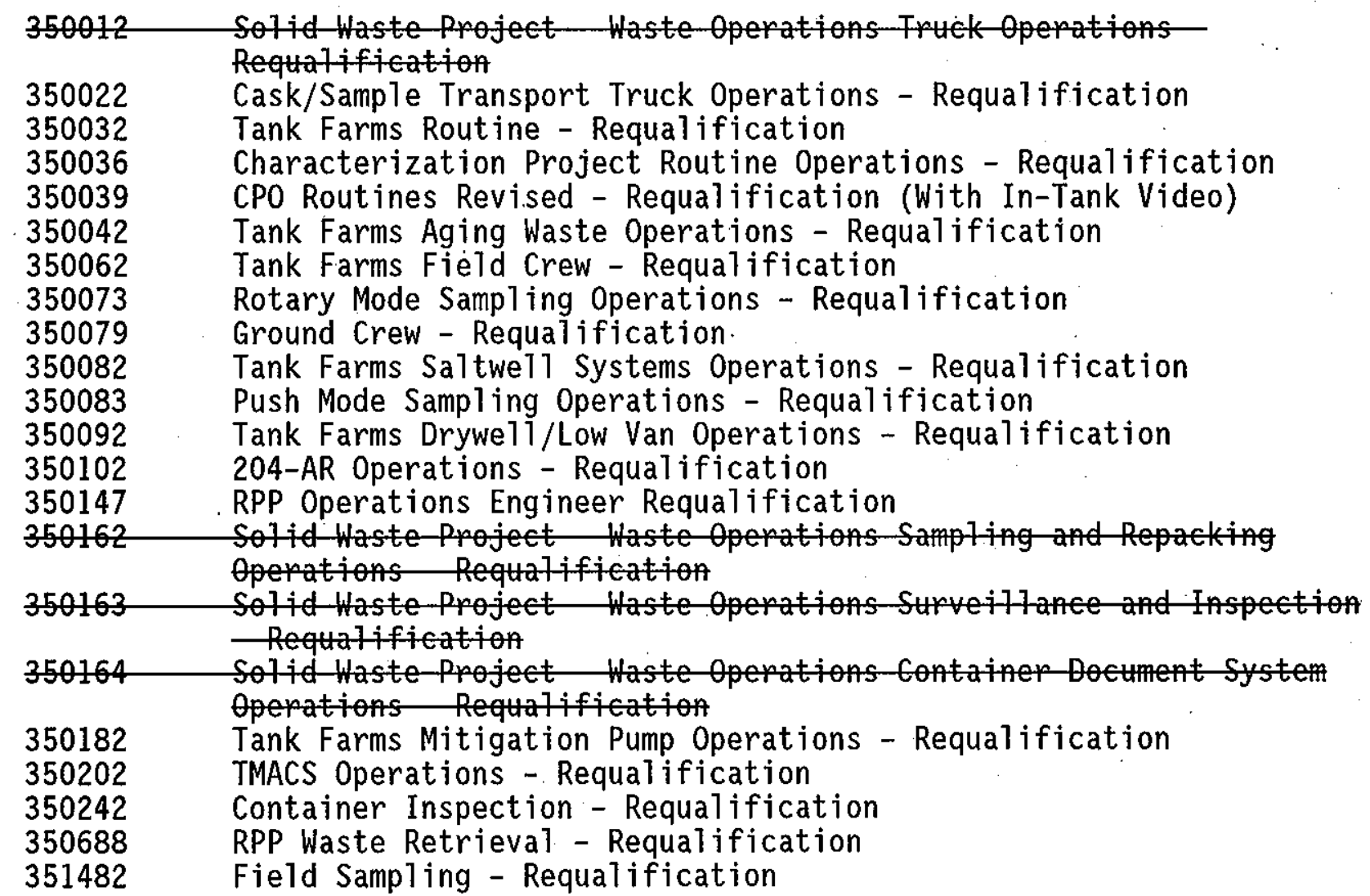

\section{COURSES SUPERSEDED BY CURRENT COURSES}

$000063 \quad$ Facility Orientation - East Tank Farm

000065

000077

$02006 S$

350110

350700

Facility Orientation - West Tank Farm

Facility Orientation - Tank Farms

Hazardous Waste Shipment Certification

Tank Farm Supervisor/Manager Certification

350750

Tank Farm East Facility Orientation

Tank Farm West Facility Orientation 
HNF-SD-WM-TR-026 Rev. 12

\section{Appendix A Training Course Descriptions}

\section{TABLE OF CONTENTS}

Appendix A-1 Dangerous Waste Operations Training Courses ....... A - 1

Appendix A-2 Job-Specific Training Courses . . . . . . . . . A - 9 
Appendix A-1 Dangerous Waste Operations Training Courses

\begin{tabular}{|c|c|}
\hline Title & 000001 Hanford General Employee Training (HGET) \\
\hline Description & $\begin{array}{l}\text { Course covers U.S. Department of Energy orders and } \\
\text { applicable policies pertaining to employer and employee } \\
\text { rights and responsibilities, general radiation training, } \\
\text { hazardous. communications and dangerous waste, fire } \\
\text { prevention, personal protective equipment, safety } \\
\text { requirements, emergency preparedness, accjent reporting, } \\
\text { and avenues for addressing safety concerns. The RCRA } \\
\text { training program identifies this course as a program } \\
\text { element as annual refresher to the Hanford Facility RCRA } \\
\text { Permit condition concerning training. }\end{array}$ \\
\hline $\begin{array}{l}\text { Mandating } \\
\text { Document }(s)\end{array}$ & Hanford Facility RCRA Permit, General Conditions II.C \\
\hline Target audience & $\begin{array}{l}\text { Al1 Hanford Facility personnel working on the Hanford } \\
\text { Facility more than one year. }\end{array}$ \\
\hline Delivery & Computer-based training with interactive video \\
\hline Evaluation & Computer generated questions \\
\hline Length & Average $=2$ to 4 Hours \\
\hline Frequency & Annual1y by 000001 \\
\hline
\end{tabular}

\begin{tabular}{|l|l|}
\hline Title & 000090 Visitor/Vendor Orientation (Video or Brochure) \\
\hline Description & $\begin{array}{l}\text { Course is designed to acquaint and familiarize visitors } \\
\text { and subcontractors with safety, security, and emergency } \\
\text { preparedness requirements and their responsibilities to } \\
\text { notify Hanford Facility personnel when situations arise. } \\
\text { In addition, this orientation ident ifies the need to obey } \\
\text { signs and labels that may be encountered regarding } \\
\text { radiological areas, hazardous materials, and dangerous } \\
\text { waste. }\end{array}$ \\
\hline $\begin{array}{l}\text { Mandating } \\
\text { Document(s) }\end{array}$ & Hanford Facility RCRA Permit, General Conditions II.C \\
\hline Target audience & $\begin{array}{l}\text { Visitors on site }>7 \text { days, including regulatory agency } \\
\text { personnel LMHC subcontractors working on the Hanford } \\
\text { Facility }<45 \text { days. }\end{array}$ \\
\hline Delivery & Video Tape or Brochure \\
\hline Evaluation & Not Applicable \\
\hline Length & 30 Minutes \\
\hline Frequency & Annually by 000090 \\
\hline
\end{tabular}


Appendix A-1 (Continued) Dangerous Waste Operations Training Courses

\begin{tabular}{||l|l||}
\hline Title & 02006G Waste Management Awareness \\
\hline Description & $\begin{array}{l}\text { Course introduces workers to federal laws governing } \\
\text { chemical safety in the work place. The course provides } \\
\text { the hazardous material/waste worker with the basic } \\
\text { fundamentals for safe use of hazardous material. Course } \\
\text { defines hazard communication and hazardous materials and } \\
\text { accumulation of waste in containers. The concepts } \\
\text { covered in this course instruct personnel on specific } \\
\text { waste generation procedures and requirements which } \\
\text { includes: (1) Pertinent waste management issues (e.g. } \\
\text { waste categories, initial accumulation container } \\
\text { management requirements, and waste segregation } \\
\text { practices) (2) proper responses to incidents pertaining } \\
\text { to the waste in the initial accumulation containers, } \\
\text { (3) Proper responses to dealing with waste of unknown } \\
\text { origins, and (4) proper responses to questions posed in } \\
\text { the field concerning the above elements. }\end{array}$ \\
\hline Mandating & $\begin{array}{l}\text { D0E-RL letter to Ecology responding to Consent order N0. } \\
\text { DE 94NM-063 } \\
\text { Hanford Facility RCRA Permit, General Conditions II.C.4 }\end{array}$ \\
\hline Document(s) & $\begin{array}{l}\text { General worker, advanced general worker, general manager, } \\
\text { and general shipper }\end{array}$ \\
\hline Target audience
\end{tabular}


Appendix A-1 (Continued) Dangerous Waste Operations Training Courses

\begin{tabular}{||l|l||}
\hline \hline Title & $\begin{array}{l}020159 \text { Hazardous Waste Shipper Qualification - Advanced } \\
\text { Course 2 }\end{array}$ \\
\hline Description & $\begin{array}{l}\text { Course introduces General Shippers to identify shippers! } \\
\text { responsibilities and } 1 \text { iabilities with regard to } \\
\text { compliance to manifesting requirements and D0T } \\
\text { regulations, including placarding, identifying proper } \\
\text { shipping names, and 10ading requirements. }\end{array}$ \\
\hline $\begin{array}{l}\text { Mandating } \\
\text { Document(s) }\end{array}$ & $\begin{array}{l}\text { WAC 173-303-330(1), -180, -190, and -370. } \\
\text { Hanford Facility RCRA Permit, General Condition II.Q. }\end{array}$ \\
\hline Target Audience & $\begin{array}{l}\text { General Shippers of dangerous or mixed waste on roadways } \\
\text { anywhere on the Hanford Facility. }\end{array}$ \\
\hline Delivery & Classroom \\
\hline Evaluation & Written examination - $80 \%$ passing grade \\
\hline Length & 24 Hours \\
\hline Frequency & Every 3 years by 020159 \\
\hline
\end{tabular}

\begin{tabular}{||l|l||}
\hline \hline Title & 035010 Waste Designation \\
\hline Description & $\begin{array}{l}\text { Course teaches dangerous waste designation according to } \\
\text { Washington Administrative Code (WAC) 173-303. Class } \\
\text { content includes section-by-section lecture on the } \\
\text { regulations, with examples following each section. } \\
\text { Students complete examples using a Waste Designation flow } \\
\text { chart. Examples addressed include: Federal Listed Waste, } \\
\text { Discarded Chemical Products, Dangerous Waste Source, } \\
\text { Washington State Criteria: Toxicity, Persistence, } \\
\text { Carcinogenic, and Federal Characteristics: Ignitability, } \\
\text { Corrosivity, Reactivity, and Toxicity. }\end{array}$ \\
\hline $\begin{array}{l}\text { Mandating } \\
\text { Document(s) }\end{array}$ & WAC 173-303-070, and -080 through -100 \\
\hline Target Audience & $\begin{array}{l}\text { General Shippers, General Manager (So7id Waste Project- } \\
\text { Waste Operators Only), Waste Designator }\end{array}$ \\
\hline Delivery & Classroom \\
\hline Evaluation & Written Exam - 80\% passing grade \\
\hline Length & 16 Hours \\
\hline Frequency & One Time \\
\hline \hline
\end{tabular}


Appendix A-1 (Continued) Dangerous Waste Operations Training Courses

\begin{tabular}{||l|l|}
\hline Title & 035012 Waste Designation Qualification \\
\hline Description & $\begin{array}{l}\text { Course provides qualification to become a waste } \\
\text { designator. }\end{array}$ \\
\hline $\begin{array}{l}\text { Mandating } \\
\text { Document(s) }\end{array}$ & WAC $173-303-070$, and -080 through -100 \\
\hline Target Audience & Waste Designators \\
\hline Delivery & Classroom \\
\hline Evaluation & Written Exam - 80\% passing grade \\
\hline Length & 4 Hours \\
\hline Frequency & Annually by 035012 \\
\hline
\end{tabular}

\begin{tabular}{||l|l||}
\hline Title & 035020 Facility Waste Sampling and Analysis \\
\hline Description & $\begin{array}{l}\text { Course presents waste sampling methodologies according to } \\
\text { EPA Protocols SW-846, Test Methods for Evaluating Solid } \\
\text { Waste Physical/Chemical Methods. This course also covers } \\
\text { documentation requirements in a sampling plan, waste. } \\
\text { analysis plan, field and laboratory quality } \\
\text { control/assurance, data quality objectives process and use } \\
\text { of actual sampling equipment as specified by WAC 173-303- } \\
110 \text {. Topics on listed waste management pertaining to } \\
\text { sample management and available on-site sampling services } \\
\text { are covered. }\end{array}$ \\
\hline $\begin{array}{l}\text { Mandating } \\
\text { Document(s) }\end{array}$ & WAC-173-303-330(1), -070, -110, and -300 \\
\hline Target audience & General Shippers \\
\hline Delivery & $\begin{array}{l}\text { Classroom presentation, exercises, demonstration and } \\
\text { discussion }\end{array}$ \\
\hline Evaluation & Written Examination - 80\% passing grade \\
\hline Length & 16 Hours \\
\hline Frequency & One Time \\
\hline
\end{tabular}


Appendix A-1 (Continued) Dangerous Waste Operations Training Courses

\begin{tabular}{||l|l||}
\hline Title & 035100 Container Waste Management - Initial \\
\hline Description & $\begin{array}{l}\text { Course covers general training requirements pertaining to } \\
\text { waste management in container at 90-day accumultion } \\
\text { areas and TSD units. The course incorporates WAC 173- } \\
303-200(1),-630, \text { DOE Orders, and LMHC policy for } \\
\text { container management. Includes practical exercises for } \\
\text { hands-on experience with the packaging of dangerous or } \\
\text { mixed waste, and preparation of packages for final } \\
\text { destination. }\end{array}$ \\
\begin{tabular}{|l} 
This course does not cover waste management aspects \\
pertaining to other RCRA waste management units such as \\
tank systems, surface impoundments, containment \\
buildings, landfills, etc.
\end{tabular} \\
\hline $\begin{array}{l}\text { Mandating } \\
\text { Document(s) }\end{array}$ & $\begin{array}{l}\text { Advanced General Workers/General Managers Services / } \\
\text { Shippers }\end{array}$ \\
\hline Target Audience 1$),-630,-200(1)$ and Waste Minimization \\
\hline Delivery & Classroom \\
\hline Evaluation & Written Examination - 80\% passing grade \\
\hline Length & 16 Hours \\
\hline Frequency & Annually by 035110 \\
\hline \hline
\end{tabular}

\begin{tabular}{||l|l|}
\hline Title & 035110 Container Waste Management - Refresher \\
\hline Description & Refreshes Course 035100 \\
\hline $\begin{array}{l}\text { Mandating } \\
\text { Document (s) }\end{array}$ & WAC $173-303-330(1),-630,-200(1)$ and Waste Minimization \\
\hline Target Audience & Advanced General Workers/General Managers/Shippers \\
\hline Delivery & Classroom \\
\hline Evaluation & Written Examination - 80\% passing grade \\
\hline Length & 4 Hours \\
\hline Frequency & Annually by 035110 \\
\hline
\end{tabular}


Appendix A-1 (Continued) Dangerous Waste Operations Training Courses

\begin{tabular}{|c|c|}
\hline Title & 035120 Waste Management Administrative - Initial \\
\hline Description & $\begin{array}{l}\text { Course is designed for personnel preparing to become } \\
\text { shippers of dangerous and/or mixed waste. This course } \\
\text { covers regulatory and company policies, forms, reports, } \\
\text { forecasts, and plans. Topics also covered include: waste } \\
\text { characterization, waste storage disposal request, low } \\
\text { level waste storage/disposal record, transuranic waste } \\
\text { storage/disposal record, and radioactive mixed waste } \\
\text { attachment sheet. In addition, students will learn how } \\
\text { these forms are used to complete shipping papers. }\end{array}$ \\
\hline $\begin{array}{l}\text { Mandating } \\
\text { Document(s) }\end{array}$ & $\begin{array}{l}\text { WAC } 173-303-330(1),-630,-200,-210,-220,-380 \text {, and - } \\
390 \text {. }\end{array}$ \\
\hline Target Audience & $\begin{array}{l}\text { General Managers (Solid-Waste-Project Waste-Operations } \\
\text { Managers Onfy)/Waste Designator }\end{array}$ \\
\hline Delivery & Classroom \\
\hline Evaluation & Written Examination - $80 \%$ passing grade \\
\hline Length & 8 Hours \\
\hline Frequency & Annually by 035130 \\
\hline
\end{tabular}

\begin{tabular}{|c|c|}
\hline Title & 035130 Waste Management Administrative - Refresher \\
\hline Description & Refreshes course 035120 \\
\hline $\begin{array}{l}\text { Mandating } \\
\text { Document }(s)\end{array}$ & $\begin{array}{l}\text { WAC } 173-303-330(1),-630,-200,-210,-220,-380 \text {, and - } \\
390 \text {. }\end{array}$ \\
\hline Target Audience & $\begin{array}{l}\text { General Managers fSolid-Waste Project Waste Operations } \\
\text { Managers Onfy)/Waste Designator }\end{array}$ \\
\hline Delivery & Classroom \\
\hline Evaluation & Written Examination - $80 \%$ passing grade \\
\hline Length & 4 Hours \\
\hline Frequency & Annually by 035130 \\
\hline
\end{tabular}


Appendix A-1 (Continued) Dangerous Waste Operations Training Courses

\begin{tabular}{|c|c|}
\hline Title & $\begin{array}{l}\text { 03E060 Facility Emergency and Hazard Information } \\
\text { Check1 ist Training (Building Emergency Plan Review for } \\
\text { HNF-IP-0263-TANKFARMS) }\end{array}$ \\
\hline Description & $\begin{array}{l}\text { Course consists of a review of specific chemical hazards } \\
\text { associated with each RCRA waste management unit and job } \\
\text { assignment, as covered by a Building Emergency Plan or a } \\
\text { supplemental Contingency Plan. The training is completed } \\
\text { by CBT or by the supervisor, manager, or a designated } \\
\text { individual using checklist A-6000-784. The unit/ } \\
\text { building-specific information is reviewed for hazards in } \\
\text { the work area and emergency response requirements, } \\
\text { including where applicable, waste feed cut-off, } \\
\text { communication and alarm systems, and response to fires. }\end{array}$ \\
\hline $\begin{array}{l}\text { Mandating } \\
\text { Document }(s)\end{array}$ & WAC $173-303-330(1)(d),-340,-350$, and -630 \\
\hline Target audience & $\begin{array}{l}\text { General Worker, General Supervisor/Manager, and General. } \\
\text { Shipper }\end{array}$ \\
\hline Delivery & $\begin{array}{l}\text { One-on-one or as a group with supervisor, manager or } \\
\text { designated individual }\end{array}$ \\
\hline Evaluation & Training checklist documentation \\
\hline Length & Average $=1$ Hour \\
\hline Frequency & Annually by $03 \mathrm{E} 060$ \\
\hline
\end{tabular}


Appendix A-1 (Continued) Dangerous Waste Operations Training Courses

\begin{tabular}{||l|l||}
\hline Title & $\begin{array}{l}350560 \text { Waste Handling Segregation and Packaging - Initial } \\
\text { (Refresher 350561) }\end{array}$ \\
\hline Description & $\begin{array}{l}\text { This course covers the proper handl ing, segregating and } \\
\text { packaging of waste within Tank Farms. The following } \\
\text { material is presented: Applicable Regulations, Waste } \\
\text { Minimization, Waste Segregation, Waste Packaging Rules } \\
\text { for handl ing Radioactive Mixed Waste, including the use } \\
\text { of Satellite Accumulation Areas, and Required Inspections } \\
\text { of Accumulation Areas and Containers. }\end{array}$ \\
\hline $\begin{array}{l}\text { Mandating } \\
\text { Document(s) }\end{array}$ & $\begin{array}{l}\text { WAC 173-303-330(1) (d), -200, -300, and waste } \\
\text { minimization. }\end{array}$ \\
\hline Target Audience & $\begin{array}{l}\text { General Workers/Advanced General Workers/General } \\
\text { Managers/General Shippers }\end{array}$ \\
\hline Delivery & Classroom \\
\hline Evaluation & Written Examination - 70\% passing grade \\
\hline Length & 4 Hours \\
\hline Frequency & Annually by 350561 \\
\hline
\end{tabular}

\begin{tabular}{||l|l||}
\hline Title & 350710 Tank Farms Facility Orientation \\
\hline Description & $\begin{array}{l}\text { Course consists of classroom presentation. Topics are } \\
\text { presented according to U.S. Department of Energy, } \\
\text { Federal, and State requirements that include entry and } \\
\text { exit requirements; 10cation of organizational charts and } \\
\text { administrative and operating procedures; the person in } \\
\text { charge of communications; potential hazards (radiological } \\
\text { and nonradiological); restricted areas; potential } \\
\text { emergencies, alarms, communications, responses and } \\
\text { staging areas; locations and use of personal protective } \\
\text { and emergency equipment; identification of TSD units; } \\
\text { overview of the process; and training requirements. }\end{array}$ \\
\hline $\begin{array}{l}\text { Mandating } \\
\text { Document(s) }\end{array}$ & WAC-173-303-330(1), -340, -350, and -360 \\
\hline Target audience & All Personnel entering RPP TSD Units \\
\hline Delivery & Classroom \\
\hline Evaluation & Written examination - 70\% passing grade \\
\hline Length & 3 Hours \\
\hline Frequency & Annually by 350760 (Computer-Based Training) \\
\hline
\end{tabular}


Appendix A-1 (Continued) Dangerous Waste Operations Training Courses.

\begin{tabular}{||l|l|}
\hline Title & 350760 Tank Farms Facility Re-Orientation \\
\hline Description & $\begin{array}{l}\text { Course consists of a review of entry and exit } \\
\text { requirements; location of organizational charts and } \\
\text { administrative and operating procedures; the person in } \\
\text { charge of communications; potential hazards (radiological } \\
\text { and nonradiologica1); restricted areas; potential } \\
\text { emergencies, alarms, communications, responses and } \\
\text { staging areas; locations and use of personal protective } \\
\text { and emergency equipment; identification of TSD units; } \\
\text { overview of the process; and training requirements. }\end{array}$ \\
\hline $\begin{array}{l}\text { Mandating } \\
\text { Document(s) }\end{array}$ & WAC-173-303-330(1), -340, -350, and -360 \\
\hline Target audience & Al1 Personnel entering RPP TSD Units \\
\hline Delivery & Computer-based Training \\
\hline Evaluation & Not app7icable \\
\hline Length & $1 / 2$ Hour \\
\hline Frequency & Annually with 000001 \\
\hline
\end{tabular}




\section{Appendix A-2 Job-Specific Training Courses}

\begin{tabular}{||l|l||}
\hline Title & 02028B Building Emergency Director Training \\
\hline Description & $\begin{array}{l}\text { Course provides an overview of the responsibilities of } \\
\text { the building emergency director, ident ifies the building } \\
\text { emergency organizations, actions required during an } \\
\text { event, implementing the contingency plan, and discusses } \\
\text { drill and exercise requirements. }\end{array}$ \\
\hline $\begin{array}{l}\text { Mandating } \\
\text { Document(s) }\end{array}$ & WAC-173-303-330(1), -340, -350, and -360 \\
\hline Target audience & $\begin{array}{l}\text { Shift Operations Managers/Operations Engineers } \\
\text { (Designated Building Emergency Directors)/Operations } \\
\text { Managers }\end{array}$ \\
\hline Delivery & At the BED office \\
\hline Evaluation & Performance Evaluation \\
\hline Length & 3.5 Hours \\
\hline Frequency & Annually by 037510 \\
\hline
\end{tabular}

\begin{tabular}{|c|c|}
\hline Title & $\begin{array}{l}037500 \text { Building Emergency Director/Building Warden } \\
\text { Requal ification }\end{array}$ \\
\hline Description & Refresher for Building Emergency Director Training \\
\hline $\begin{array}{l}\text { Mandating } \\
\text { Document (s) }\end{array}$ & WAC $-173-303-330(1),-340,-350$, and -360 \\
\hline Target audience & $\begin{array}{l}\text { Operations Shift Managers/Operations Engineers } \\
\text { (Designated Building Emergency Directors)/Operations } \\
\text { Managers }\end{array}$ \\
\hline Delivery & C1assroom \\
\hline Evaluation & Not Applicable \\
\hline Length & 1.5 Hours \\
\hline Frequency & Annually by 037510 \\
\hline
\end{tabular}




\section{Appendix A-2 (Continued) Job-Specific Training Courses}

\begin{tabular}{|c|c|}
\hline Fitte & $\begin{array}{l}350010 \text { solid Waste Project Waste Operations Truck } \\
\text { Operations Initial Qualification-(Requalification } \\
350012 \text { ) }\end{array}$ \\
\hline Beseription & 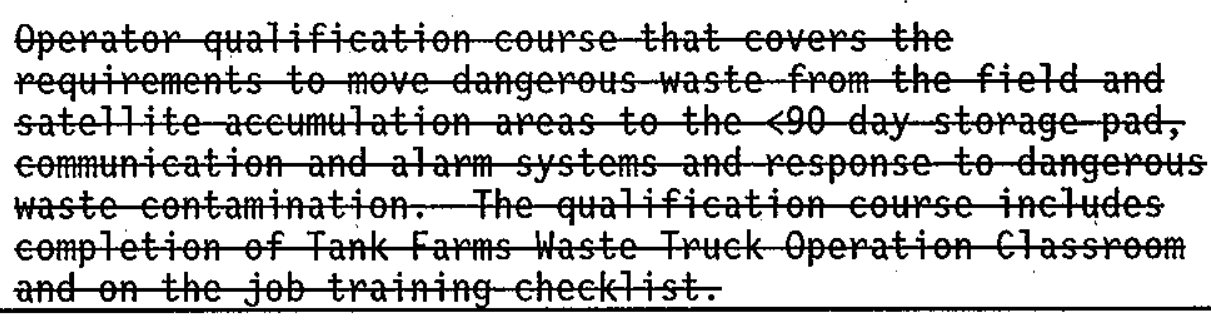 \\
\hline $\begin{array}{l}\text { Mandating } \\
\text { Bocument (s) }\end{array}$ & WAC $173-303-330,-400-$ ON 600 \\
\hline Farget audience & Huclear Chemical operators \\
\hline Betivery & Elassroom, On The Job Training \\
\hline Evaluation & $\begin{array}{l}\text { Written-Examination } 70 \% \text { passing-grade, Perfomance } \\
\text { Bemonstration }\end{array}$ \\
\hline tength & Approximately 20 Hours \\
\hline Frequency & Every 2 years by 350012 \\
\hline
\end{tabular}

\begin{tabular}{||l|l||}
\hline \hline Title & $\begin{array}{l}350020 \text { Cask/Sample Transport Truck Operations - Initial } \\
\text { Qual ification (Requalification 350022) }\end{array}$ \\
\hline Description & $\begin{array}{l}\text { Operator qual ification course that covers the } \\
\text { requirements to transport samples from the field to the } \\
\text { laboratories. The qual ification course includes } \\
\text { completion of Cask/Sample Transport Truck Operations } \\
\text { Classroom and on-the-job training checklist. }\end{array}$ \\
\hline $\begin{array}{l}\text { Mandating } \\
\text { Document(s) }\end{array}$ & WAC-173-303-330, -400 or -600 \\
\hline Target audience & Nuclear Chemical Operators \\
\hline Delivery & Classroom, On-the-Job Training \\
\hline Evaluation & $\begin{array}{l}\text { Written Examination - 70\% passing grade, Performance } \\
\text { Demonstration }\end{array}$ \\
\hline Length & Approximately 40 Hours \\
\hline Frequency & Every 2 years by 350022 \\
\hline
\end{tabular}


Appendix A-2 (Continued) Job-Specific Training Courses

\begin{tabular}{||l|l||}
\hline Title & $\begin{array}{l}350030 \text { Tank Farms Routine Operations - Initial } \\
\text { Qualification (RequaT ification 350032) }\end{array}$ \\
\hline Description & $\begin{array}{l}\text { Operator qualification course that defines the } \\
\text { function, components, principles of operation, and } \\
\text { purpose of Tank Farms Routine operations, Covers A7 arm } \\
\text { response and normal operating procedures including: } \\
\text { procedures for using, inspecting and replacing RPP } \\
\text { emergency and monitoring equipment, automatic and manual } \\
\text { dangerous waste feed cut-off systems, response to fire } \\
\text { and explosions, response to spi1ls and shutdown of } \\
\text { operations. }\end{array}$ \\
\hline $\begin{array}{l}\text { Mandating } \\
\text { Document(s) }\end{array}$ & WAC-173-303-330, -400 or -600 \\
\hline Target audience & Nuclear Chemical 0perators \\
\hline Delivery & Classroom, 0n-The-Job Training \\
\hline Evaluation & $\begin{array}{l}\text { Written Examination - 70\% passing grade, Performance } \\
\text { Demonstration }\end{array}$ \\
\hline Length & Approximately 160 hrs \\
\hline Frequency & Every 2 Years by 350032. \\
\hline
\end{tabular}

\begin{tabular}{||l|l||}
\hline Title & 350031 Tank Farms Routines Classroom \\
\hline Description & $\begin{array}{l}\text { This classroom training teaches Operators how to perform } \\
\text { duties associated with routine surveillance, waste } \\
\text { transfers and ventilation in Tank Farms. Conduct of } \\
\text { Operations, equipment, alarm response, radiation control, } \\
\text { and safety requirements are also covered. }\end{array}$ \\
\hline $\begin{array}{l}\text { Mandating } \\
\text { Document(s) }\end{array}$ & WAC-173-303-330, -400 or -600 \\
\hline Target audience & Nuclear Chemical Operators \\
\hline Delivery & Classroom \\
\hline Evaluation & Written Examination - 70\% passing grade \\
\hline Length & Approximately $160 \mathrm{hrs}$ \\
\hline Frequency & Initial Training \\
\hline
\end{tabular}


Appendix A-2 (Continued) Job-Specific Training Courses

\begin{tabular}{||l|l||}
\hline Title & $\begin{array}{l}350035 \text { Characterization Project Routine Operations - } \\
\text { Initial Qual ification (Requalification 350036) }\end{array}$ \\
\hline Description & $\begin{array}{l}\text { Operator qualification course that defines the } \\
\text { function, components, principles of operation and } \\
\text { purpose of CP0 Routines. Covers procedures for using, } \\
\text { inspecting and replacing tools and equipment and response } \\
\text { to spills. }\end{array}$ \\
\hline $\begin{array}{l}\text { Mandating } \\
\text { Document(s) }\end{array}$ & WAC-173-303-330, -400 or -600 \\
\hline Target audience & Nuclear Chemical Operators \\
\hline Delivery & Classroom, On-The-Job Training \\
\hline Evaluation & $\begin{array}{l}\text { Written Examination - 70\% passing grade, Performance } \\
\text { Demonstration }\end{array}$ \\
\hline Length & Approximately 40 Hours \\
\hline Frequency & Every 2 Years by 350036 \\
\hline
\end{tabular}

\begin{tabular}{||l|l|}
\hline Title & 350037 CPO In-Tank Video (Requalification 350039) \\
\hline Description & $\begin{array}{l}\text { Supplemental course that defines the function, } \\
\text { components, principles of operation and } \\
\text { purpose of CPO In-Tank Video, Covers procedures for } \\
\text { using, inspecting and replacing tools and equipment used } \\
\text { for In-Tank Video. }\end{array}$ \\
\hline $\begin{array}{l}\text { Mandating } \\
\text { Document(s) }\end{array}$ & WAC-173-303-330, -400 or -600 \\
\hline Target audience & Nuclear Chemical Operators \\
\hline Delivery & Classroom, On-The-Job Training \\
\hline Evaluation & $\begin{array}{l}\text { Written Examination - 70\% passing grade, Performance } \\
\text { Demonstration }\end{array}$ \\
\hline Length & Approximately 1 Hour \\
\hline Frequency & Every 2 Years by 350039 \\
\hline
\end{tabular}


Appendix A-2 (Continued) Job-Specific Training Courses

\begin{tabular}{||l|l|}
\hline Title & $\begin{array}{l}350040 \text { Tank Farms Aging Waste Operations - Initial } \\
\text { Qualification (Requal ification 350042) }\end{array}$ \\
\hline Description & $\begin{array}{l}\text { Operator qual ification course that defines the } \\
\text { function, components, principles of operation, and } \\
\text { purpose of Aging Waste operations. Covers Alarm Response } \\
\text { Procedures and normal operating procedures including: } \\
\text { procedures for using, inspecting and replacing RPP } \\
\text { emergency and monitoring equipment, automatic and manual } \\
\text { dangerous waste feed cut-off systems, response to fire } \\
\text { and explosions, response to spills and shutdown of } \\
\text { operations. }\end{array}$ \\
\hline $\begin{array}{l}\text { Mandating } \\
\text { Document(s) }\end{array}$ & WAC-173-303-330, -400 or -600 \\
\hline Target audience & Nuclear Chemical Operators \\
\hline Delivery & Classroom, On-The-Job Training \\
\hline Evaluation & $\begin{array}{l}\text { Written Examination - 70\% passing grade, Performance } \\
\text { Demonstration }\end{array}$ \\
\hline Length & Approximately 40 hrs \\
\hline Frequency & Every 2 Years by 350042 \\
\hline
\end{tabular}

\begin{tabular}{||l|l|}
\hline Title & $\begin{array}{l}350060 \text { Tank Farms Field Crew - Initial Qualification } \\
\text { (Requalification 350062) }\end{array}$ \\
\hline Description & $\begin{array}{l}\text { Operator qualification course that defines the } \\
\text { function, components, principles of operation and } \\
\text { purpose of Field Crew. Covers procedures for using, } \\
\text { inspecting and replacing tools and equipment and response } \\
\text { to spills. }\end{array}$ \\
\hline $\begin{array}{l}\text { Mandating } \\
\text { Document(s) }\end{array}$ & WAC-173-303-330, -400 or -600 \\
\hline Target audience & Nuclear Chemical Operators \\
\hline Delivery & Classroom, On-The-Job Training \\
\hline Evaluation & $\begin{array}{l}\text { Written Examination - 70\% passing grade, Performance } \\
\text { Demonstration }\end{array}$ \\
\hline Length & Approximately 60 Hours \\
\hline Frequency & Every 2 Years by 350062 \\
\hline
\end{tabular}


Appendix A-2 (Continued) Job-Specific Training Courses

\begin{tabular}{|c|c|}
\hline Fitle & $\begin{array}{l}350065 \text { solid Waste Project Waste-Operations Operations } \\
\text { Elassroom }\end{array}$ \\
\hline Beseription & 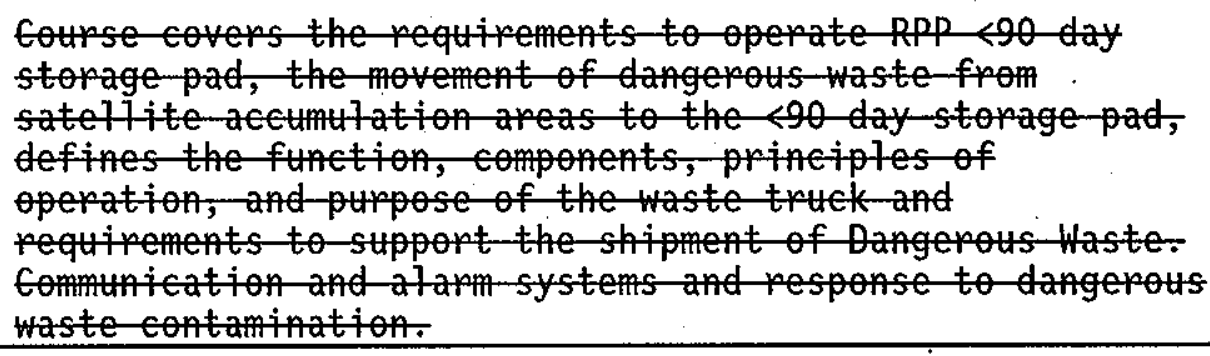 \\
\hline $\begin{array}{l}\text { Mandating } \\
\text { Bocument(s) }\end{array}$ & WAC $173-303-330,400$ or 600 \\
\hline Farget audience & Solid Waste Project, Advanced-General Workers \\
\hline Betivery & Elassroom \\
\hline Evaluation & $\begin{array}{l}\text { Written Examination } 70 \% \text { passing grade for nuclear } \\
\text { operators, 80\% for Solid- Waste Project Waste-Operations } \\
\text { Feam teaders }\end{array}$ \\
\hline tength & Approximatefy-8-Houns \\
\hline Frequency & One-Time \\
\hline
\end{tabular}

\begin{tabular}{||l|l||}
\hline \hline Title & $\begin{array}{l}350070 \text { Push Mode Sampling Operations - Initial } \\
\text { Qualification (Requalification 350083) }\end{array}$ \\
\hline Description & $\begin{array}{l}\text { Operator qual ification course that defines the function, } \\
\text { components, principles of operation and purpose of Push } \\
\text { Mode Core Sampling Platform Operations. }\end{array}$ \\
\hline $\begin{array}{l}\text { Mandating } \\
\text { Document(s) }\end{array}$ & WAC-173-303-330,-400 or -600 \\
\hline Target audience & Nuclear Chemical Operators \\
\hline Delivery & Classroom, On-The-Job Training \\
\hline Evaluation & $\begin{array}{l}\text { Written Examination - 70\% passing grade, Performance } \\
\text { Demonstration }\end{array}$ \\
\hline Length & Approximately 40 Hours \\
\hline Frequency & Every 2 Years by 350083 \\
\hline
\end{tabular}


Appendix A-2 (Continued) Job-Specific Training Courses

\begin{tabular}{||l|l|}
\hline Title & $\begin{array}{l}350075 \text { Rotary Mode Sampling Operations - Initial } \\
\text { Qualification (Requal ification 350073) }\end{array}$ \\
\hline Description & $\begin{array}{l}\text { Operator qualification course that defines the } \\
\text { function, components, principles of operation and } \\
\text { purpose of Rotary Mode Sampling Platform Operations. }\end{array}$ \\
\hline $\begin{array}{l}\text { Mandating } \\
\text { Document (s) }\end{array}$ & WAC-173-303-330, -400 or -600 \\
\hline Target audience & Nuclear Chemical Operators \\
\hline Delivery & Classroom, On-The-Job Training \\
\hline Evaluation & $\begin{array}{l}\text { Written Examination - 70\% passing grade, Performance } \\
\text { Demonstration }\end{array}$ \\
\hline Length & Approximately 40 Hours \\
\hline Frequency & Every 2 Years by 350073 \\
\hline
\end{tabular}

\begin{tabular}{||l|l||}
\hline Title & $\begin{array}{l}350077 \text { Ground Crew - Initial Qualification } \\
\text { (Requal ification 350079) }\end{array}$ \\
\hline Description & $\begin{array}{l}\text { Operator qual ification course that defines the } \\
\text { function, components, principles of operation and } \\
\text { purpose of Push and Rotary Mode Sampling Ground Crew } \\
\text { Operations. }\end{array}$ \\
\hline $\begin{array}{l}\text { Mandating } \\
\text { Document(s) }\end{array}$ & WAC-173-303-330, -400 or -600 \\
\hline Target audience & Nuclear Chemical Operators \\
\hline Delivery & Classroom, On-The-Job Training \\
\hline Evaluation & $\begin{array}{l}\text { Written Examination - 70\% passing grade, Performance } \\
\text { Demonstration }\end{array}$ \\
\hline Length & Approximately 40 Hours \\
\hline Frequency & Every 2 Years by 350079 \\
\hline
\end{tabular}


Appendix A-2 (Continued) Job-Specific Training Courses

\begin{tabular}{||l|l||}
\hline Title & $\begin{array}{l}350080 \text { Tank Farms Saltwel1 Systems Operations - Initial } \\
\text { Qualification (Requal ification 350082) }\end{array}$ \\
\hline Description & $\begin{array}{l}\text { Operator qual ification course that defines the } \\
\text { function, components, principles of operation, and } \\
\text { purpose of Saltwe17 Systems operations. Covers Alarm } \\
\text { Response Procedures and normal operating procedures } \\
\text { including: procedures for automatic and manual dangerous } \\
\text { waste feed cut-off systems, response to spills and } \\
\text { shutdown of operations. }\end{array}$ \\
\hline $\begin{array}{l}\text { Mandating } \\
\text { Document(s) }\end{array}$ & WAC-173-303-330, -400 or -600 \\
\hline Target audience & Nuclear Chemical Operators \\
\hline Delivery & Classroom, On-The-Job Training \\
\hline Evaluation & $\begin{array}{l}\text { Written Examination - 70\% passing grade, Performance } \\
\text { Demonstration }\end{array}$ \\
\hline Length & Approximately 24 Hours \\
\hline Frequency & Every 2 Years by 350082 \\
\hline
\end{tabular}

\begin{tabular}{||l|l||}
\hline Title & $\begin{array}{l}\text { 350090 Tank Farms Drywe11/Low Van Operations - Initial } \\
\text { Qualification (Requalification 350092) }\end{array}$ \\
\hline Description & $\begin{array}{l}\text { Operator qual ification course that defines the } \\
\text { function, components, principles of operation, and } \\
\text { purpose of Drywe11/Low Van operations and In-Tank } \\
\text { Photography and Video Taping. Covers alarm response and } \\
\text { normal operating procedures. }\end{array}$ \\
\hline $\begin{array}{l}\text { Mandating } \\
\text { Document(s) }\end{array}$ & WAC-173-303-330, -400 or -600 \\
\hline Target audience & Nuclear Chemical Operators \\
\hline Delivery & Classroom, On-The-Job Training \\
\hline Evaluation & $\begin{array}{l}\text { Written Examination - 7.0\% passing grade, Performance } \\
\text { Demonstration }\end{array}$ \\
\hline Length & Approximately 24 Hours \\
\hline Frequency & Every 2 Years by 350092 \\
\hline
\end{tabular}


Appendix A-2 (Continued) Job-Specific Training Courses

\begin{tabular}{|l|l||}
\hline Title & $\begin{array}{l}350100 \text { 204-AR Operations - Initial Qualification } \\
\text { (Requal ification 350102) }\end{array}$ \\
\hline Description & $\begin{array}{l}\text { Operator qualification course that defines the } \\
\text { function, components, principles of operation, and } \\
\text { purpose of 204-AR Building operations. Covers Alarm } \\
\text { Response Procedures and normal operating procedures } \\
\text { including: Automatic and manual dangerous waste feed } \\
\text { cut-off systems, response to fire and explosions, } \\
\text { response to spi17s and shutdown of operations. }\end{array}$ \\
\hline $\begin{array}{l}\text { Mandating } \\
\text { Document(s) }\end{array}$ & WAC-173-303-330, -400 or -600 \\
\hline Target audience & Nuclear Chemical Operators \\
\hline Delivery & Classroom, On-The-Job Training \\
\hline Evaluation & $\begin{array}{l}\text { Written Examination - 70\% passing grade, Performance } \\
\text { Demonstration }\end{array}$ \\
\hline Length & Approximately 40 Hours \\
\hline Frequency & Every 2 Years by 350102 \\
\hline
\end{tabular}

\begin{tabular}{|c|c|}
\hline Title & $\begin{array}{l}350145 \text { RPP Operations Engineer Qualification } \\
\text { (Requal ification } 350147 \text { ) }\end{array}$ \\
\hline Description & $\begin{array}{l}\text { Course includes the following topics to prepare the } \\
\text { Manager in Tank Farms operations: } \\
\text { - Administrative information } \\
\text { - Technical information } \\
\text { - Hazardous material/dangerous waste requirements } \\
\text { - Safling dangerous waste } \\
\text { - Operationalysis reports } \\
\text { - Radiation work proceduires } \\
\text { - Occurrence reporting } \\
\text { - Cobs conducted in the area of assigned responsibility } \\
\text { - Processes and services } \\
\text { - Equipment. }\end{array}$ \\
\hline $\begin{array}{l}\text { Mandating } \\
\text { Document }(s)\end{array}$ & WAC- $173-303-330,-400$ or -600 \\
\hline Target audience & Shift Operations Managers/Operations Engineers \\
\hline Delivery & Classroom, On-The--Job Training \\
\hline Evaluation & Written Examination - $80 \%$ passing grade, Oral Board \\
\hline Length & 240 Hours \\
\hline Frequency & Every 2 years by 350147 \\
\hline
\end{tabular}


Appendix A-2 (Continued) Job-Specific Training Courses

\begin{tabular}{|c|c|}
\hline Fitle & $\begin{array}{l}\text { 350165-Solid-Waste-project Waste-Operations Sampling } \\
\text { and Repacking-Operations Initial Qualification } \\
\text { (Requalification 350162) }\end{array}$ \\
\hline Bescription & 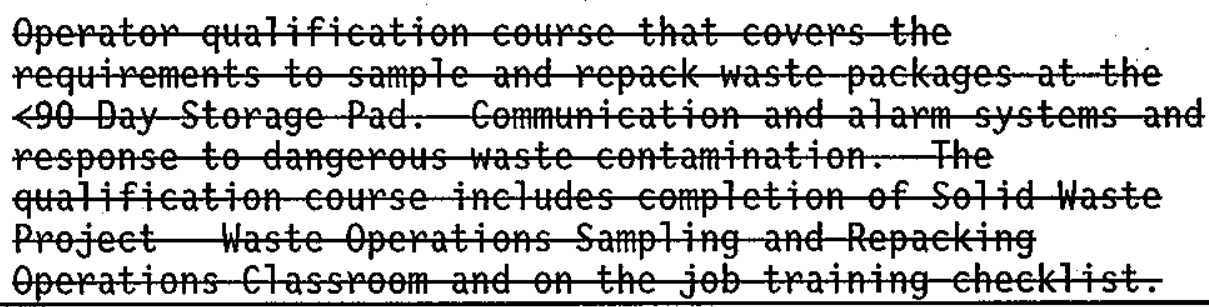 \\
\hline $\begin{array}{l}\text { Mandating } \\
\text { Bocument (s) }\end{array}$ & WAC $173-303-330,-400$ or 600 \\
\hline Farget audience & Nuclear Chemical-Operators \\
\hline Befivery & Elassroom, 0 n The Job Training \\
\hline Evaltation & $\begin{array}{l}\text { Written Examination } 70 \% \text { passing-grade, Performance } \\
\text { Bemonstration }\end{array}$ \\
\hline tength & Approximate $7 y-40$ Hours \\
\hline Frequency & Every 2 years by 350162 \\
\hline
\end{tabular}


Appendix A-2 (Continued) Job-Specific Training Courses

\begin{tabular}{|c|c|}
\hline Fitte & $\begin{array}{l}350166 \text { solid Waste project Waste-0perations } \\
\text { Strveillance and Inspection Intial Qutalification } \\
\text { (Requalification } 350163 \text { ) }\end{array}$ \\
\hline Beseniption & 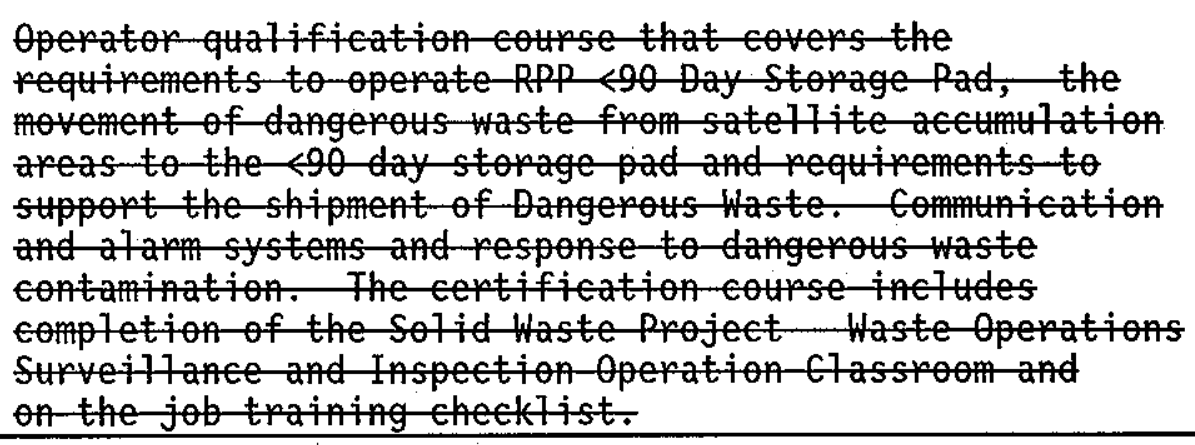 \\
\hline $\begin{array}{l}\text { Mandating } \\
\text { Boeument (s) }\end{array}$ & HAC $173-303-330,-400$ OP -600 \\
\hline Farget audience & Aluctear Chemical Operators \\
\hline Delivery & Elassroom, On The Job Training \\
\hline Evaluation & $\begin{array}{l}\text { Written Examination } 70 \% \text { passing grade, Performance } \\
\text { Bemonstration }\end{array}$ \\
\hline tength & Approximately 40 - Hours \\
\hline Frequency & Every 2 years by 350163 \\
\hline
\end{tabular}




\section{Appendix A-2 (Continued) Job-Specific Training Courses}

\begin{tabular}{|c|c|}
\hline Fitte & $\begin{array}{l}350167 \text { Solid Waste Project Waste Operations Container } \\
\text { Document System/0ispatch Initial Qualifieation } \\
\text { (Requalifieation 350164) }\end{array}$ \\
\hline Description & $\begin{array}{l}\text { Coupse covers the requirements to operate-the } \\
\text { Envimonmentai Waste Operations Container Boetment System } \\
\text { to keep track of the Dangerous and Mixed Waste } \\
\text { accumutated-by RPP. }\end{array}$ \\
\hline $\begin{array}{l}\text { Mandating } \\
\text { Bocument (s) }\end{array}$ & WAC $173-303-330,-400$ or 600 \\
\hline Farget atulience & Alletear Chemical-Operators \\
\hline Belivery & Elassroom, on The Job-Training \\
\hline Evaluation & By-examination, Performance-Demonstration \\
\hline tength & $\mathrm{NA}$ \\
\hline Frequency & Every 2 years 350164 \\
\hline
\end{tabular}

\begin{tabular}{||l|l||}
\hline Title & $\begin{array}{l}\text { 350180 Tank Farms Mitigation Pump Operations - Initial } \\
\text { Qualification (Requal ification 350182) }\end{array}$ \\
\hline Description & $\begin{array}{l}\text { Operator qual ification course that defines the } \\
\text { function, components, principles of operation, and } \\
\text { purpose of Tank Farms Mitigation Pump operations. Covers } \\
\text { Alarm response and normal operating procedures. }\end{array}$ \\
\hline $\begin{array}{l}\text { Mandating } \\
\text { Document (s) }\end{array}$ & WAC-173-303-330, -400 or -600 \\
\hline Target audience & Nuclear Chemical Operators \\
\hline Delivery & Classroom, On-The-Job Training, Performance Demonstration \\
\hline Evaluation & $\begin{array}{l}\text { Written Examination - 70\% passing grade, Performance } \\
\text { Demonstration }\end{array}$ \\
\hline Length & Approximately 40 Hours \\
\hline Frequency & Every 2 Years by 350182 \\
\hline
\end{tabular}


Appendix A-2 (Continued) Job-Specific Training Courses

\begin{tabular}{||l|l||}
\hline \hline Title & $\begin{array}{l}\text { 350201 TMACS Operations - Initial Qualification } \\
\text { (Requalification 350202) }\end{array}$ \\
\hline Description & $\begin{array}{l}\text { Operator qual ification course that defines the } \\
\text { function, components, principles of operation, and } \\
\text { purpose of the the TMACS. Covers Alarm Response } \\
\text { Procedures and normal operating procedures. }\end{array}$ \\
\hline $\begin{array}{l}\text { Mandating } \\
\text { Document(s) }\end{array}$ & WAC-173-303-330, -400 or -600 \\
\hline Target audience & Nuclear Chemical Operators \\
\hline Delivery & Classroom, On-The-Job Training \\
\hline Evaluation & $\begin{array}{l}\text { Written Examination - 70\% passing grade, Performance } \\
\text { Demonstration }\end{array}$ \\
\hline Length & Approximately 24 Hours \\
\hline Frequency & Every 2 Years by 350202 \\
\hline
\end{tabular}

\begin{tabular}{||l|l||}
\hline Title & $\begin{array}{l}\text { 350241 Container Inspection - Initial Qualification } \\
\text { (Classroom - 350240, Requal ification 350242) }\end{array}$ \\
\hline Description & $\begin{array}{l}\text { Operator qual ification that teaches the procedures for } \\
\text { safe inspection of containers of Mixed, Low-Leve1, } \\
\text { Dangerous/Hazardous, Nonregulated and Recycle wastes. } \\
\text { This qualification also teaches the methods of safe } \\
\text { inspection of Radioactive Material Storage Areas. }\end{array}$ \\
\hline $\begin{array}{l}\text { Mandating } \\
\text { Document(s) }\end{array}$ & $\begin{array}{l}\text { WAC-173-303-630 (Waste Container Inspection) } \\
\text { HNF-IP-0842, VII, 2.10 (Radioactive Material Storage Area } \\
\text { Inspection) }\end{array}$ \\
\hline Target audience & Nuclear Chemical Operators \\
\hline Delivery & Classroom, On-The-Job Training \\
\hline Evaluation & $\begin{array}{l}\text { Written Examination - 70\% passing grade, Followed by a } \\
\text { Performance Demonstration }\end{array}$ \\
\hline Length & Classroom 4 Hours \\
\hline Frequency & Every 2 Years by 350242 \\
\hline
\end{tabular}


Appendix A-2 (Continued) Job-Specific Training Courses

\begin{tabular}{||l|l||}
\hline \hline Title & $\begin{array}{l}\text { 350510 Tank Farms Person-In-Charge (PIC) Qualification - } \\
\text { Initial \& Refresher }\end{array}$ \\
\hline Description & $\begin{array}{l}\text { PIC Qualification Training consists of three phases: } \\
\text { Procedural Reviews (required reading), On-The-Job } \\
\text { Training, and Performance Evaluations. These phases } \\
\text { provide the PIC candidate with facility specific } \\
\text { experience, an understanding of administrative procedures } \\
\text { associated with their area(s) of responsibilities, and a } \\
\text { comprehensive evaluation of their performance. The } \\
\text { course is designed to prepare/qualify individuals } \\
\text { responsible for the quantity and quality of work } \\
\text { performed and who coordinate the actions of operators, } \\
\text { technicians and maintenance personnel. }\end{array}$ \\
\hline Mandating \\
Document(s)
\end{tabular}

\begin{tabular}{||l|l||}
\hline Title & $\begin{array}{l}\text { 350680 RPP Waste Retrieval Qualification - Initial } \\
\text { (Requal ification 350688) }\end{array}$ \\
\hline Description & $\begin{array}{l}\text { Train Operators on all aspects of Sluicing operations, } \\
\text { including operation of peripheral equipment. }\end{array}$ \\
\hline $\begin{array}{l}\text { Mandating } \\
\text { Document(s) }\end{array}$ & WAC 173-303-330, -400 or -600 \\
\hline Target audience & Nuclear Chemical Operators \\
\hline Delivery & Classroom, On-The-Job Training \\
\hline Evaluation & $\begin{array}{l}\text { Written Examination - 70\% passing grade, Performance } \\
\text { Demonstration }\end{array}$ \\
\hline Length & Approximately 40 Hours \\
\hline Frequency & Every 2 Years by 350688 \\
\hline
\end{tabular}


Appendix A-2 (Continued) Job-Specific Training Courses

\begin{tabular}{||l|l||}
\hline Title & $\begin{array}{l}\text { 351479 Field Sampling - Initial Qualification } \\
\text { (Requalification 351482) }\end{array}$ \\
\hline Description & $\begin{array}{l}\text { Operator qualification course that defines the } \\
\text { function, components, principles of operation and } \\
\text { purpose of Vapor, Auger, and Grab Sampling. }\end{array}$ \\
\hline $\begin{array}{l}\text { Mandating } \\
\text { Document(s) }\end{array}$ & WAC-173-303-330, -400 or -600 \\
\hline Target audience & Nuclear Chemical Operators \\
\hline Delivery & Classroom, On-The-Job Training \\
\hline Evaluation & $\begin{array}{l}\text { Written Examination - 70\% passing grade, Performance } \\
\text { Demonstration }\end{array}$ \\
\hline Length & Approximately 40 Hours \\
\hline Frequency & Every 2 Years by 351482 \\
\hline
\end{tabular}

